\title{
Comparison of clumped isotope signatures of dolomite cements to fluid inclusion thermometry in the temperature range of 73 to $176{ }^{\circ} \mathrm{C}$
}

Rosemarie E. Came ${ }^{\mathrm{a}, *}$, Karem Azmy ${ }^{\mathrm{b}}$, Aradhna K. Tripati ${ }^{\mathrm{c}}$, and Babatunde-John Olanipekun ${ }^{\mathrm{b}}$

${ }^{a}$ Department of Earth Sciences, University of New Hampshire, Durham, New Hampshire 03824, USA.

${ }^{b}$ Department of Earth Sciences, Memorial University of Newfoundland, St John's, Newfoundland A1B 3X5, Canada.

${ }^{c}$ Department of Earth, Planetary, and Space Sciences, Department of Atmospheric and Oceanic Sciences, Institute of the Environment and Sustainability, University of California, Los Angeles, California 90095, USA. European Institute of Marine Sciences (IUEM), Université de Bretagne Occidentale, UMR 6538/6539, Rue Dumont D'Urville, and IFREMER, Plouzané, France.

* Corresponding author. Tel: +1 603862 1720; fax: +1 603862 2649; E-mail address: Rosemarie.Came@unh.edu (R.E.Came).

\section{ABSTRACT}

Widespread application of the novel clumped isotope paleothermometer $\left(\Delta_{47}\right)$ using dolomite samples from shallow crustal settings has been hindered by a lack of adequate constraints on clumped isotope systematics in dolomites that formed at temperatures greater than $50{ }^{\circ} \mathrm{C}$. 
Consequently, many high-temperature applications involving diagenetic dolomites have required an assumption that the relationship between temperature and $\Delta_{47}$ in diagenetic dolomite resembles the theoretical temperature dependence for calcite. Here we present $\Delta_{47}$ results from dolomite cements for which precipitation temperatures were determined independently using fluid inclusion microthermometry. We compare a rock-based "calibration" for samples from the temperature range of $\sim 73$ to $176^{\circ} \mathrm{C}$ to previously published laboratory-derived calibrations for synthetic calcites. This novel combination of approaches yields results that are broadly consistent with results reported from controlled laboratory experiments, providing an important confirmation of the utility of clumped isotopes in real-world systems. Our results suggest that the $\Delta_{47}$ of dolomite cements may provide key information in the reconstruction of burial and thermal histories and also in the recognition of potential petroleum reservoirs.

\section{INTRODUCTION}

In the years since its introduction in 2006 (Ghosh et al., 2006a), the carbonate "clumped isotope" paleothermometer $\left(\Delta_{47}\right)$, which utilizes the thermodynamically controlled "clumping" of

${ }^{13} \mathrm{C}$ and ${ }^{18} \mathrm{O}$ as recorded in carbonate minerals, has been applied to a variety of geoscience questions that were previously thought to be intractable (Ghosh et al., 2006b; Came et al., 2007; Garzione et al., 2008; Affek et al., 2008; Eagle et al., 2010; Huntington et al., 2010; Passey et al., 2010; Csank et al., 2011; Eagle et al., 2011; Huntington et al., 2011; Keating-Bitonti et al., 2011; Finnegan et al., 2011; Brand et al., 2012; Tripati et al., 2014; Dale et al., 2014; Kluge et al., 2014). The utility of this novel proxy spans a broad range of subdisciplines within the geosciences, with recent applications including: paleoaltimetry reconstructions of the Andes 
(Ghosh et al., 2006b) and the Colorado Plateau (Huntington et al., 2010); estimates of the body temperatures of dinosaurs and other extinct vertebrates (Eagle et al., 2010; Eagle et al., 2011); reconstructions of diagenetic and burial histories (Budd et al., 2013; Ferry et al., 2011;

Huntington et al., 2011; Bristow et al., 2011; Loyd et al., 2012; Dale et al., 2014; Henkes et al., 2014; Shenton et al., 2015); investigations into the evolution of the early solar system using meteorites (Guo and Eiler, 2007; Halevy et al., 2011); and paleoclimate reconstructions using paleosols (Passey et al., 2010; Suarez et al., 2011; Eagle et al., 2013; Quade et al., 2013), carbonate fossils (Came et al., 2007; Csank et al., 2011; Finnegan et al., 2011; Keating-Bitoni et al., 2011; Zaarur et al., 2011; Brand et al., 2012; Tripati et al., 2014; Douglas et al., 2014), and speleothems (Affek et al., 2008; Daëron et al., 2011; Kluge et al., 2014).

The application of the $\Delta_{47}$ paleothermometer in the reconstruction of burial and diagenetic histories (Ferry et al., 2011; Huntington et al., 2011; Bristow et al., 2011; Loyd et al., 2013; Dale et al., 2014; Henkes et al., 2014) is of increasing interest, particularly because it can help ascertain whether or not a potential petroleum reservoir rock experienced temperatures in excess of the oil and gas "windows" ( $\sim 50$ to 150 and 150 to $200{ }^{\circ} \mathrm{C}$, respectively) (Peters et al., 2005). However, many applications involving diagenetic temperatures utilize the mineral dolomite, for which calibration data are limited. Dolomites are calcium magnesium carbonate minerals that are predominantly secondary and are not primary, except for protodolomites found in sabkhas, and occur in both low and high temperature settings. Notably, the single published comprehensive $\Delta_{47}$ calibration equation for temperatures greater than $77^{\circ} \mathrm{C}$ (Kluge et al., 2015) is limited to the mineral calcite, though there is one unpublished calibration data set involving dolomites in the 50 to $350^{\circ} \mathrm{C}$ range (Bonifacie et al, 2011). 
In addition to a paucity of data for dolomite, the published calibration results for calcite diverge. Many of the early applications of the $\Delta_{47}$ paleothermometer involved data that were generated within a single laboratory (Caltech), which is where the initial $\Delta_{47}$ to temperature calibration was derived (Ghosh et al., 2006a). This calibration, which used synthetic carbonates that precipitated at known temperatures, revealed a relationship between temperature and $\Delta_{47}$ that exhibited greater temperature sensitivity than the theoretical (Schauble et al., 2006; Guo et al., 2009). It was unclear whether this mismatch arose from uncertainties in theoretical calculations, fractionation during acid digestion, and/or other factors (Dennis et al., 2011). In the years since the publication of the initial calibration, multiple groups have established clumped isotope laboratories, and they have conducted new calibration experiments using a variety of carbonate types and using an assortment of laboratory protocols (Ghosh et al., 2007; Dennis and Schrag, 2010; Tripati et al., 2010; Thiagarajan et al., 2011; Saenger et al., 2012; Eagle et al., 2013; Grauel et al., 2013; Henkes et al., 2013; Zaarur et al., 2013; Fernandez et al., 2014; Tang et al., 2014; Came et al., 2014; Wacker et al., 2014; Defliese et al., 2015; Kluge et al., 2015). This has resulted in multiple discrepant calibration equations, and has made it difficult to determine whether the discrepant calibrations result from differences in laboratory protocols (e.g. Wacker et al., 2014; Defliese et al., 2015), from actual differences in the $\Delta_{47}$ to temperature relationships of various types of carbonates (i.e., kinetic isotope effects as discussed in Hill et al., 2014a; Tripati et al., 2015), or cation substitution (per Hill et al., 2014b, Yuan, 2015). One striking observation, however, is that there appear to be two main clusters of calibrations: one cluster that resembles the equation initially derived by the group at Caltech (Ghosh et al., 2006a; Ghosh et al., 2007; Tripati et al., 2010, 2015; Thiagarajan et al., 2011; Grauel et al., 2013; Zaarur et al., 2013; Came et al., 2014; Kimball et al., 2015); and another cluster that resembles an equation 
derived by the group at Harvard (Dennis and Schrag, 2010; Tang et al., 2014; Wacker et al., 2014; Defliese et al., 2015; Kluge et al., 2015). The establishment of a common interlaboratory "absolute reference frame" for reporting $\Delta_{47}$ (Dennis et al., 2011) has not brought the discrepant calibrations into agreement. Notably, both types of calibrations have been reported based on measurements of samples precipitated at $<50{ }^{\circ} \mathrm{C}$ using different methods, made on the same instrument and reacted for analysis using the same digestion apparatus (Tang et al., 2014; Tripati et al., 2015). In addition, both types of calibrations have been observed in deep-sea coral of variable mineralogy, also measured on the same system (Kimball et al., 2015).

One way to investigate the reason(s) for the discrepancies is to obtain $\Delta_{47}$ calibration data for samples that grew at high temperatures, where extrapolations of the published equations diverge substantially. Until recently, no comprehensive calibration study had been published for calcites that precipitated at temperatures greater than $77^{\circ} \mathrm{C}$. The recent results of Kluge et al. (2015), however, extend the empirical calibration to include calcites that precipitated at temperatures of up to $250^{\circ} \mathrm{C}$, and the results of carbonate mineral heating experiments (Ghosh et al., 2006a; Guo et al., 2009; Passey and Henkes, 2012; Henkes et al., 2014; Stolper and Eiler, 2015; Tripati et al., $2015)$ produce "anchors" at still higher temperatures $\left(475\right.$ to $\left.>1000{ }^{\circ} \mathrm{C}\right)$. Some of these studies (Passey and Henkes, 2012; Kluge et al., 2015; Stolper and Eiler, 2015) provide improved constraints on the slope of the inorganic calcite calibration equation, and confirm earlier results (Dennis and Schrag, 2010; Tang et al., 2014; Wacker et al., 2014; Defliese et al., 2015) suggesting that calcites reacted in phosphoric acid at high temperature $\left(70\right.$ to $\left.90^{\circ} \mathrm{C}\right)$ yield a calibration equation with a slope that is similar to the slope predicted by theory (Schauble et al., 2006; Guo et al., 2009). Furthermore, these high temperature studies (Passey and Henkes, 2012; Kluge et al., 2015; Stolper and Eiler, 2015) provide empirical validation for the approach of 
other authors (Dennis and Schrag, 2010; Ferry et al., 2011; Huntington et al., 2011; Bristow et al., 2011; Budd et al., 2013; Dale et al., 2014; Henkes et al., 2014; Shenton et al., 2015) who used the theoretical equations (Schauble et al., 2006; Guo et al., 2009) for their reconstructions of burial and diagenetic histories.

The lack of data for dolomite, and the uncertainty over calibrations, particularly at high temperatures, motivated the present study. Specifically, we aim to validate the application of this geothermometer to dolomites grown at high temperatures $\left(\sim 73\right.$ to $\left.176^{\circ} \mathrm{C}\right)$ using geological samples, analogous to the taxon specific biogenic calibrations that have been published for temperatures ranging from 0 to $30^{\circ} \mathrm{C}$ (e.g., Came et al., 2014; Eagle et al., 2010; Tripati et al., 2010; Thiagarajan et al., 2011; Grauel et al., 2013). We compare new $\Delta_{47}$ results from dolomite cements to precipitation temperatures that were determined independently using fluid inclusion microthermometry (Azmy et al., 2008; Azmy et al., 2009; Azmy and Conliffe, 2010; Azomani et al., 2013; Olanipekun et al., 2014). Fluid inclusions are tiny fluid-filled vacuoles within minerals that retain remnants of the fluid from which the enclosing mineral precipitated, and record the temperature at which that enclosing phase grew (Shepherd et al., 1985; Goldstein and Reynolds, 1994; Goldstein, 2003). Although there are uncertainties associated with the interpretation of fluid inclusion temperatures, they are subject to different sources of uncertainty than clumped isotope thermometry and may be subject to fewer sources of error. The $\Delta_{47}$ measurements presented here were performed on materials that were microdrilled from the same spots where fluid inclusion temperatures were measured. We compare our rock-based dolomite "calibration" to published theoretical and empirical results, and show that our new data are broadly consistent with a range of published calibrations, confirming the utility of the clumped isotope technique when applied to dolomites from high temperature shallow crustal environments. 


\section{GEOLOGIC SETTING AND LITHOSTRATIGRAPHY}

Samples were collected from the Boat Harbour, Catoche, and Aguathuna formations of the Lower Ordovician St. George Group of western Newfoundland, Canada (Figure 1). The rocks of the St. George Group consist of tropical, shallow water carbonates that were deposited on a wide, peritidal carbonate ramp (James, 1989). Sedimentation of these shallow marine carbonates began during the Middle to Late Cambrian when high-energy carbonates of the Port-au-Port Group were deposited. These were succeeded by Early to earliest Middle Ordovician low-energy carbonates of the St. George Group (cf. Knight, 2008). Taconic fore-arc forcing resulted in distal lithospheric upwarping and rapid sweeping of a tectonic peripheral bulge on the margin, which led to compression, block faulting, uplift, and erosion of the St. George carbonate platform and development of the regional St. George Unconformity (Mussman and Read, 1986; Knight, 2008) (Figure 2A). A subsequent, tectonically driven local sea level rise accommodated deposition of the superjacent deepening-upward carbonates of the Table Head Group (Stenzel et al., 1990; Knight, 2008).

Lower Paleozoic successions deposited on the Laurentia shallow marine platform margin are characterized by a thick Middle Cambrian to lower Middle Ordovician carbonate bank. Lithostratigraphy of the St. George Group has been discussed in detail and refined in multiple studies (e.g. Pratt and James, 1986; Knight and James, 1987; Knight, 2008). The lithostratigraphic framework (Figure 2A) is briefly summarized here. The St. George Group consists of early Ordovician (Tremadoc-Arenig) platform carbonates (500 m thick), which from bottom to top include the Watts Bight, Boat Harbour, Catoche, and Aguathuna formations 
(Figure 2A). The upper boundary of the St. George Group (Aguathuna/Table Point formational contact) is marked by the major regional St. George Group Unconformity (SGU; Figure 2A). The St. George Group can be divided into two sedimentary megacycles separated by the Boat Harbour Disconformity (BHD; Figure 2A). Each megacycle is characterized by a large-scale transgressive-regressive succession that resulted in stacking of lower peritidal, middle subtidal and upper peritidal units (Knight and James, 1987; Knight, 2008). Multiple stages of dolomitization affected the St. George Group carbonates (Azmy et al., 2008; Azmy et al., 2009; Azmy and Conliffe, 2010; Azomani et al., 2013; Olanipekun et al., 2014).

\section{PREVIOUSLY PUBLISHED WORK ON THE ST. GEORGE GROUP SAMPLES}

\subsection{Previously published petrographic results}

The dolomite samples investigated in the present work (Table 1) have been studied extensively by previous authors (Azmy et al., 2008; Azmy et al., 2009; Azmy and Conliffe, 2010; Azomani et al., 2013; Olanipekun et al., 2014). Petrographic and geochemical studies indicate that the rocks of the St. George Group experienced multiple phases of dolomitization (D1, D2, and D3; Figure 2B and C). These phases are found together, though the formation of each was associated with increasing/progressive burial (Azmy et al., 2008; Azmy et al., 2009; Azmy and Conliffe, 2010; Azomani et al., 2013; Olanipekun et al., 2014). D1 is fabric-retentive (e.g., algal lamination) dolomicrite, with micritic to near-micritic grain size (Figure 2B), and insignificant presence of spar, that exhibits a dull to non-luminescence under cathodoluminoscope and was formed at near-surface conditions. D2 has larger eu- to subhedral 
(60 to $400 \mu \mathrm{m}$; Figure 2C) crystals with cloudy cores and clear rims, which exhibit zoned cathodoluminescence (CL). It developed during progressive replacement of limestones or recrystallization of D1 at mid-burial settings. D3 is a vug- and fracture filling "saddle" dolomite with large anhedral crystals $(0.5$ to $\geq 2 \mathrm{~mm})$ that exhibit dull CL. Saddle dolomites are defined as having curved crystal faces, and they are believed to have formed in deeper burial environments (Azmy et al., 2008; Azmy et al., 2009; Azmy and Conliffe, 2010; Azomani et al., 2013; Olanipekun et al., 2014).

\subsection{Previously published fluid inclusion microthermometry results}

Table 1 lists previously published homogenization temperatures $\left(\mathrm{T}_{h}\right)$ for primary two-phase fluid inclusions (Goldstein and Reynolds, 1994; Bodnar, 2003a) from the D2 and D3 phases of dolomitization (Azmy et al., 2008; Azmy et al., 2009; Azmy and Conliffe, 2010; Azomani et al., 2013; Olanipekun et al., 2014). Fluid inclusions are tiny vacuoles ( $\sim 7$ to $10 \mu \mathrm{m})$ that retain remnants of the fluid from which the dolomite precipitated. Because the integrity of a primary two-phase fluid inclusion remains intact over geologic time, the $\mathrm{T}_{h}$ of that inclusion reflects the temperature at which the enclosing mineral phase precipitated (Shepherd et al., 1985; Goldstein and Reynolds, 1994; Goldstein, 2003). The $\Delta_{47}$ measurements presented in the current study were performed on materials that were microdrilled from the same spots where $\mathrm{T}_{h}$ values were measured. Previous work (Azmy et al., 2008; Azmy et al., 2009; Azmy and Conliffe, 2010; Azomani et al., 2013; Olanipekun et al., 2014) indicates that the inclusions in our selected suites are primary: they occur parallel to crystal facets and have a consistent liquid : vapor ratio (e.g., Goldstein, 2003). Furthermore, the $\mathrm{T}_{h}$ values of each selected suite of primary fluid inclusions 
vary within $<15^{\circ} \mathrm{C}$ (Table 1), confirming their primary nature (Goldstein and Reynolds, 1994; Goldstein, 2003).

The measured $\mathrm{T}_{h}$ values of the St. George Group dolomites are similar to the range of temperatures $\left(\sim 75\right.$ to $\left.160^{\circ} \mathrm{C}\right)$ concluded from burial history studies (Cooper et al., 2001), conodont alteration index (CAI), acritarch alteration indices (AAI), and graptolite reflectance from the Lower Ordovician rocks of western Newfoundland (Nowlan and Barnes, 1987; Williams et al., 1998). No $\mathrm{T}_{h}$ values were obtained for D1 dolomicrites because inclusions were too small, though the fabric-retentive textures and near-micritic grain sizes suggest formation at near-surface conditions with temperatures below $\sim 50{ }^{\circ} \mathrm{C}$ (Olanipekun et al., 2014; cf. Gradstein and Reynolds, 1994).

\subsection{Previously published parent fluids results}

Previous work involving petrography, trace/minor element geochemistry, stable isotope geochemistry, fluid inclusion microthermometry, and fluid inclusion halide geochemistry indicates that the D1, D2 and D3 dolomites of the St. George Group originated from parent diagenetic fluids that reflect progressively deeper burial environments (Azmy et al., 2008; Azmy et al., 2009; Conliffe et al., 2009; Azmy and Conliffe, 2010; Azomani et al., 2013; Olanipekun et al., 2014). These parameters indicate that the D1 dolomites (dolomicrites) precipitated at nearsurface conditions, from dolomitizing fluids with oxygen isotopic signatures (approx. $-8.1 \%$ to $5.8 \%$ ) and $\mathrm{Sr} / \mathrm{Ca}$ molar ratios $(<0.008)$ indicative of a mixture of seawater and meteoric waters (Azmy et al., 2009; Olanipekun et al., 2014). Thus, it is likely that D1 dolomicrites formed by dolomitization of micritic lime mudstones during very early stages of diagenesis by mixed 
waters (likely marine and meteoric). The micritic to near-micritic grain size and absence of twophase fluid inclusions are consistent with dolomitization being driven by replacement at lowtemperatures by these mixed fluids.

The D2 and D3 dolomites precipitated in hotter burial settings. After dolomitization turned C1 micrites into D1 dolomicrites, it is argued that in some cases, in a mid-burial setting, hotter fluids $\left(>60^{\circ} \mathrm{C}\right)$ recrystallized D1 into D2, resulting in increased crystal size and the development of primary two-phase fluid inclusions. D3 dolomites precipitated in a deeper environment than D2 dolomites (Azmy et al., 2008; Azmy et al., 2009; Azomani et al., 2013; Conliffe et al., 2010). The halide geochemistry of the entrapped fluids in these phases suggests that the dolomitizing fluids originated from slightly evaporated seawater that may have been partially diluted by meteoric waters (Conliffe et al., 2010; Conliffe et al., 2012).

\section{METHODS}

No new microthermometric measurements were performed as part of the current study, but results from previous investigations were utilized. In summary, the previously published $\mathrm{T}_{h}$ measurements were performed using a state-of-the-art Linkam THMSG600 heating-freezing stage calibrated with synthetic fluid inclusion standards at temperatures between $-56.6{ }^{\circ} \mathrm{C}$ and $374.1^{\circ} \mathrm{C}$. Precision on individual $\mathrm{T}_{\mathrm{h}}$ measurements was better than $\pm 1{ }^{\circ} \mathrm{C}$ (e.g., Olanipekun et al., 2014). Homogenization temperatures were recorded first in order to minimize the effects of stretching in relatively soft minerals following procedures outlined by Shepherd et al. (1985).

The isotopic analyses conducted as part of the present study were performed using the same samples that were used to generate the previously published $\mathrm{T}_{h}$ data. All dolomite samples were 
analyzed blindly in the Tripati Laboratory at the University of California Los Angeles (UCLA), following procedures described elsewhere (Affek and Eiler, 2006; Huntington et al., 2009; Passey et al., 2010; Loyd et al., 2013). Analyses were performed using an automated carbonate device (e.g. Passey et al., 2010) coupled with a Thermo-Finnigan MAT253 gas-source isotope ratio mass spectrometer configured to collect masses 44 to 49 . Each analysis consisted of an $\sim 8$ mg aliquot of dolomite sample powder, which was digested for 20 minutes in $105 \% \mathrm{H}_{3} \mathrm{PO}_{4}$ at 90 ${ }^{\circ} \mathrm{C}($ density $=1.92 \mathrm{~g} / \mathrm{mL})$, with acid being changed every 8-10 sample analyses or more frequently if the color changed, if the reaction vessel appeared dirty, or if the magnet was not rotating. Acid density was checked when a new bottle was first opened, when it was $1 / 3$ full, and when it was nearly empty. Water and other contaminating phases were removed from the product $\mathrm{CO}_{2}$ using a dry ice and ethanol slush. Any additional contaminating phases, such as hydrocarbons, were removed by passing sample $\mathrm{CO}_{2}$ through a gas chromatograph column (Porapak Q 120/80 mesh, $122 \mathrm{~cm}$ long, $2.15 \mathrm{~mm}$ ID) at $-20^{\circ} \mathrm{C}$, and by passing the sample through a silver foil trap. Each analysis consisted of 8 acquisitions, each of which consisted of 8 cycles of back-and-forth sample to reference gas comparisons (reference gas $\delta^{18} \mathrm{O}_{\mathrm{VSMOW}}=$ $25.06 \%$; $\delta^{13} \mathrm{C}_{\mathrm{VPDB}}=-3.61 \%$ ), for a total of 64 cycles per analysis. The ${ }^{17} \mathrm{O}$ correction of Santrock et al. (1985) was applied. Data for 34 analyses are reported.

In order to account for mass spectrometric nonlinearities and for scale compression associated with ion source chemistry, raw $\Delta_{47}$ values were normalized using a suite of 25 and $1000{ }^{\circ} \mathrm{C}$ equilibrated gases of various bulk isotopic compositions. Data are reported in the absolute reference frame that was calculated using these equilibrated gases, with equilibrated gas slopes and transfer functions provided in Supplemental Table 1. All $\Delta_{47}$ data are reported in a manner consistent with a $25^{\circ} \mathrm{C}$ reaction temperature by the application of an acid digestion correction of 
$0.082 \%$ to convert from 90 to $25^{\circ} \mathrm{C}$ (Defliese et al., 2015). This correction is statistically indistinguishable from the $0.092 \%$ correction reported by Henkes et al. (2013) and the corrections summarized by Wacker et al. (2013), and it is applicable for both dolomite and calcite (Defliese et al., 2015). We note that an alternative acid digestion fractionation factor of 0.153\%o has recently been published by Murray et al. (2016).

For the calculation of the stable oxygen isotope values of dolomite $\left(\delta^{18} \mathrm{O}_{\mathrm{d}}\right)$, we applied a fractionation factor of 1.0093 (Rosenbaum and Sheppard, 1986) to account for the temperaturedependent fractionation of oxygen isotopes between dolomite and $\mathrm{CO}_{2}$ gas that results from the reaction with phosphoric acid at $90{ }^{\circ} \mathrm{C}$. The oxygen isotopic compositions of parent fluids $\left(\delta^{18} \mathrm{O}_{\mathrm{w}}\right)$ were calculated using $\delta^{18} \mathrm{O}_{\mathrm{d}}$, the previously published $\mathrm{T}_{h}$ values, and the equation of Horita (2014).

Long-term reproducibility of a Carrerra Marble standard in the Tripati laboratory is better than $0.1 \%$ o $(1 \sigma)$ for $\delta^{18} \mathrm{O}_{\mathrm{d}}$ and $\delta^{13} \mathrm{C}$ before standardization and better than $0.01 \%$ after standardization. The long-term average $\Delta_{47}$ value of the internal Carrara Marble (CM) standard is $0.386 \pm$ 0.002\% (s.e., $\mathrm{n}=72 ; 1 \sigma=0.017$ ). Values for internal $\mathrm{CM}$ standards reported in Dennis et al. (2011) include $0.392 \pm 0.007 \%$ o $(n=18)$ for Caltech, $0.385 \pm 0.005 \%$ o $(n=40)$ for Harvard, $0.403 \pm 0.006 \%$ o $(n=8)$ for Johns Hopkins, and $0.400 \pm 0.004 \%$ or for Yale $(n=49)$. Note that these are analyses on separate blocks of CM and therefore there may be some heterogeneity in primary values between laboratories. Table 2 reports the $\Delta_{47}$ and $\delta^{18} \mathrm{O}$ standard values for the runs in which our data were generated.

\section{RESULTS}


All $\delta^{18} \mathrm{O}_{\mathrm{d}}$ and $\Delta_{47}$ data generated as part of this study are provided in Supplemental Table 1. Mean $\delta^{18} \mathrm{O}_{\mathrm{d}}$ and $\Delta_{47}$, as well as the calculated $\delta^{18} \mathrm{O}_{\mathrm{w}}$, are presented in Table 1.

\subsection{Oxygen isotope results}

Oxygen isotopic compositions of the dolomite cements $\left(\delta^{18} \mathrm{O}_{\mathrm{d}}\right)$ range from $-12.5 \%$ o to $-6.4 \%$ o (Table 1; Figure 3A), in agreement with published $\delta^{18} \mathrm{O}_{\mathrm{d}}$ results from these same formations (Azmy et al., 2008; Azmy et al., 2009; Conliffe et al., 2009; Azmy and Conliffe, 2010; Azomani et al., 2013; Olanipekun et al., 2014). The decrease in $\delta^{18} \mathrm{O}_{\mathrm{d}}$ with increasing $\mathrm{T}_{h}$ is consistent with petrographic results that indicate progressively deeper burial of the St. George Group sediments: initial precipitation (D1) occurred at low temperatures at near surface conditions; and subsequent precipitation (D2 and D3) occurred at higher temperatures in deeper burial environments (Azmy et al., 2008; Azmy et al., 2009; Conliffe et al., 2009; Azmy and Conliffe, 2010; Azomani et al., 2013; Olanipekun et al., 2014).

The calculated $\delta^{18} \mathrm{O}$ values of diagenetic waters $\left(\delta^{18} \mathrm{O}_{\mathrm{w}}\right)$ in equilibrium with the dolomites for each $\mathrm{T}_{h}$ and $\delta^{18} \mathrm{O}_{\mathrm{d}}$ pair range from $-3.2 \%$ to $6.8 \%$ (Table 1 ; Figure $3 \mathrm{~B}$ ). As with $\delta^{18} \mathrm{O}_{\mathrm{d}}$, the $\delta^{18} \mathrm{O}_{\mathrm{w}}$ results agree with published results from these same formations (Azmy et al., 2008; Azmy et al., 2009; Conliffe et al., 2009; Azmy and Conliffe, 2010; Azomani et al., 2013; Olanipekun et al., 2014). Our calculated $\delta^{18} \mathrm{O}_{\mathrm{w}}$ values for $\mathrm{D} 1$ dolomites (-3.1\%o and -3.2\%o) are higher than the range reported previously (approx. -8.1\%o to -5.8\%; Azmy et al., 2009; Olanipekun et al., 2014), but they overlap with the published range when error is considered (Figure $3 \mathrm{~B}$ ). Higher $\delta^{18} \mathrm{O}_{\mathrm{w}}$ values (1.1\%o to $6.8 \%$ ) for the D2 and D3 dolomites are consistent with previous interpretations that these phases precipitated in deeper burial settings from high temperature brines that mixed 
with dilute fluids, such as meteoric waters (Azmy et al., 2008; Azmy et al., 2009; Azomani et al., 2013; Conliffe et al., 2010; Conliffe et al., 2012).

\subsection{Clumped isotope results}

The mean $\Delta_{47}$ values of the samples in our suite range from $0.437 \%$ to $0.532 \%$ (Table 1 ; Figure 4). These values are all low relative to the $\Delta_{47}$ of carbonates that record typical Earth surface temperatures (e.g. Zaarur et al., 2011; Henkes and Passey, 2013; Wacker et al., 2014; many others), and are consistent with diagenetic temperatures. In general, the $\Delta_{47}$ values of the St. George Group samples decrease with progressively higher $\mathrm{T}_{h}$ (Figure 4$)$.

Figure 4 suggests that the clumped isotope signatures of some of the samples in our suite were reordered to lower values than expected based on their fluid inclusion temperatures (See Section 6.1 below for the discussion of reordering). The $\Delta_{47}$ values of the two D1 samples from the Boat Harbour formation $(0.514 \pm 0.010 \%$ and $0.530 \pm 0.010 \%)$ are statistically indistinguishable from the $\Delta_{47}$ of the three D2 samples from that same formation (0.509 \pm $0.003 \%, 0.490 \pm 0.004 \%$, and $0.532 \pm 0.012 \%$ ) despite the very different fluid inclusion temperatures for those phases (for both D1 samples $\mathrm{T}_{h}<50{ }^{\circ} \mathrm{C}$; for $\mathrm{D} 2, \mathrm{~T}_{h}=121.3 \pm 9.4{ }^{\circ} \mathrm{C}$, $121.3 \pm 9.4{ }^{\circ} \mathrm{C}$, and $103.1 \pm 6.2{ }^{\circ} \mathrm{C}$ ). Similarly, the $\Delta_{47}$ of the D2 sample from the Catoche formation $\left(0.456 \pm 0.007 \%\right.$ ) is within error of the $\Delta_{47}$ of the D3 sample from that same formation $\left(0.445 \pm 0.012 \%\right.$ o), though the fluid inclusion temperatures of those phases are $123.6 \pm 1.0^{\circ} \mathrm{C}$ and $175.9 \pm 7.3{ }^{\circ} \mathrm{C}$ respectively. Only one sample from the Aguathuna formation was analyzed, precluding a similar comparison for that formation. 


\section{DISCUSSION}

\subsection{Possible modification of initial $T_{h}$ and/or $\Delta_{47}$ signatures}

\subsubsection{Primary nature of fluid inclusions}

We consider the possibility that the initial $\mathrm{T}_{h}$ signatures of the St. George Group samples were altered by geologic processes that occurred after the formation of the dolomites and the entrapment of the fluid inclusions. As described in Section 3.2 above, fluid inclusions retain remnants of the fluid from which the enclosing mineral phase precipitated, and the measured $\mathrm{T}_{h}$ of that inclusion reflects the temperature of precipitation, assuming that no subsequent reequilibration of the fluid inclusion occurred (Shepherd et al., 1985; Goldstein and Reynolds, 1994; Goldstein, 2003). Re-equilibration occurs if the inclusion volume changes, or if anything is added to or lost from the inclusion following entrapment (Bodnar, 2003b).

In order to assess the likelihood of re-equilibration of the fluid inclusions, the St. George Group samples were examined comprehensively using conventional optical microscopy, cathodoluminescence, and fluid inclusion assemblages (Azmy et al., 2008; Azmy et al., 2009; Azmy and Conliffe, 2010; Azomani et al., 2013; Olanipekun et al., 2014). Optical microscopy and cathodoluminescence provide diagnostic evidence about re-equilibration of a fluid inclusion because the deformation caused by re-equilibration leads to distinctive textural changes in mineral host phases (Goldstein, 2003). Fluid inclusion assemblages provide further evidence because individual two-phase (liquid + vapor) fluid inclusions within a fluid inclusion assemblage should have consistent liquid : vapor ratios if no re-equilibration has occurred, as is well established in the field of fluid inclusion microthermometry (e.g., Goldstein, 2003). Finally, 
if no re-equilibration has occurred, the $\mathrm{T}_{h}$ values within a suite of fluid inclusions should not vary widely. The results of previous studies involving the St. George Group samples yield no evidence that re-equilibration of the fluid inclusions occurred (Azmy et al., 2008; Azmy et al., 2009; Azmy and Conliffe, 2010; Azomani et al., 2013; Olanipekun et al., 2014). Furthermore, the $\mathrm{T}_{h}$ values within each of our selected suites of primary fluid inclusions vary within $<15^{\circ} \mathrm{C}$ (Table 1), which confirms their primary nature (Goldstein and Reynolds, 1994; Goldstein, 2003).

\subsubsection{Solid-state clumped isotope exchange reactions}

The $\Delta_{47}$ values presented in this study were generated using the same dolomite samples from which the fluid inclusion temperatures were previously obtained. Therefore, if no reequilibration of the fluid inclusions occurred after precipitation, then the fluid inclusion temperature and the $\Delta_{47}$-derived temperature of a given dolomite sample should be equal unless $\Delta_{47}$ was modified after mineral growth. As of this date, no comprehensive $\Delta_{47}$ to temperature calibration for dolomites has been published, so it is not possible to compare $\mathrm{T}_{h}$ values to $\Delta_{47^{-}}$ derived temperatures using an existing empirical calibration. However, unpublished calibration data from natural and synthetic dolomites grown at known temperatures from 25 to $350{ }^{\circ} \mathrm{C}$ (Bonifacie et al., 2011) have been shown to resemble the Guo et al. (2009) theoretical temperature dependence for calcite. Furthermore, the limited dolomite calibration data of Ferry et al. (2011; two data points from $\left.<45^{\circ} \mathrm{C}\right)$ support this notion. Therefore, we follow the lead of previous authors (e.g. Bristow et al., 2011; Ferry et al., 2011; Budd et al., 2013; Dale et al., 2014; Shenton et al., 2015) and tentatively assume that the $\Delta_{47}$ to temperature dependence for dolomite resembles the theoretical relationship for calcite. The clumped isotope temperatures that our $\Delta_{47}$ 
values imply based on the theoretical temperature dependence for calcite (Schauble et al., 2006; Guo et al., 2009) are provided in Table 3.

Comparison of our results to the theoretical relationship (Figure 4; Table 3) indicates that the $\Delta_{47}$ signatures of some (or perhaps all) of the St. George Group samples were modified after mineral growth by thermally activated solid-state isotope exchange reactions (e.g. Passey and Henkes, 2012; Henkes et al., 2014; Stolper and Eiler, 2015). We also note that it is not necessary to know the relationship between temperature and the $\Delta_{47}$ of dolomite in order to make this inference. The D1 dolomites from Boat Harbour precipitated during an early stage of diagenesis in a near-surface to shallow burial environment (as indicated by relative fabric preservation, near micritic crystal size, and dull CL response), yet they have $\Delta_{47}$ signatures $(\sim 0.52 \% 0)$ that are similar to the values for the later-forming D2 dolomites from that same formation $(\sim 0.51 \%)$, which precipitated later, and in deeper and hotter environments $\left(\sim 115^{\circ} \mathrm{C}\right)$. Similarly, the D2 dolomite from the Catoche formation has a $\Delta_{47}$ signature $(0.456 \%)$ that is similar to the signature of the later- and deeper-forming (hotter) D3 sample $(0.445 \%$ ) from that same formation. Furthermore, the D2 dolomite from the Aguathuna formation has a $\Delta_{47}$ signature $(0.486 \%)$ that is lower than that of the D2 dolomites from Boat Harbour ( 0.51\%), yet the Boat Harbour samples precipitated at temperatures that were 40 to $50^{\circ} \mathrm{C}$ hotter. Dissolution and recrystallization are unlikely explanations for these observations because the suites of fluid inclusions within each of these D2 phases retained their primary nature (Section 6.1.1). Therefore, we conclude that the $\Delta_{47}$ signatures of these samples must have been modified by solid-state isotope exchange reactions.

On the other hand, the clumped isotope signatures of a subset of the St. George Group dolomites appear to have remained unmodified. For example, the $\Delta_{47}$ of the D2 Boat Harbour 
samples agree fairly well with the theoretical predictions (Figure 4; Figure 5). This suggests that these samples may not have experienced detectable solid-state isotope exchange, as solid-state reordering in these samples would imply initial $\Delta_{47}$ signatures that were greater than those predicted by any clumped isotope calibration to date.

Modification after mineral growth of the $\Delta_{47}$ signatures of the St. George Group dolomites by solid-state isotope exchange reactions is an unexpected result in light of recent work that predicts no detectable reordering in dolomites held at temperatures less than $\sim 250^{\circ} \mathrm{C}$ over timescales of up to $10^{8}$ years (Lloyd and Eiler, 2014), and also in light of previous work suggesting a dolomite blocking temperature in a slowly cooled system of $\sim 300{ }^{\circ} \mathrm{C}$ (Eiler, 2011; Ferry et al., 2011). $\mathrm{T}_{h}$ values from the St. George Group fluid inclusions, which record the temperatures of dolomitizing fluids, do not exceed $200{ }^{\circ} \mathrm{C}$ (Table 1), and previously published burial history studies - which include data from conodont alteration index, acritarch alteration indices, and graptolite reflectance - suggest that the Lower Ordovician rocks of western Newfoundland were not exposed to burial temperatures in excess of $160^{\circ} \mathrm{C}$ (Nowlan and Barnes, 1987; Williams et al., 1998; Cooper et al., 2001). Therefore, it is difficult to reconcile our new results with previous estimates of the dolomite blocking temperature (Eiler, 2011; Lloyd and Eiler, 2014; Ferry et al., 2011).

One possible explanation for this disagreement is that the susceptibility of the mineral dolomite to thermally activated solid-state isotope exchange may be greater than estimated by previous authors (Eiler, 2011; Lloyd and Eiler, 2014; Ferry et al., 2011). Kinetic models involving the mineral calcite (e.g. Passey and Henkes, 2012; Henkes et al., 2014; Stolper and Eiler, 2015) predict that detectable solid-state reordering in that mineral can occur at temperatures above $\sim 115^{\circ} \mathrm{C}$ on timescales of $10^{6}$ to $10^{8}$ years, and that complete re-equilibration 
can occur at temperatures greater than $200{ }^{\circ} \mathrm{C}$ in most geological environments (Henkes et al., 2014). Furthermore, recent work involving laboratory shearing experiments suggests that calcite may be susceptible to reordering in high stress environments (Siman-Tov et al., 2016). If the susceptibility of the mineral dolomite were more akin to that of calcite, then the initial $\Delta_{47}$ signatures of the earlier forming dolomite phases may have been reordered due to the documented heating of the St. George Group. Reordering without recrystallization leaves no physical evidence that the inferred $\Delta_{47}$ temperature is disconnected from crystallization temperature, though it could potentially be detected by examining trends with burial depth if sufficient data exist, by assessing the relationship between $\Delta_{47}$ and other geochemical parameters (e.g., Loyd et al., 2015), or possibly by using imaging techniques such as electron backscatter diffraction (Henkes et al., 2014). These types of analyses could potentially be targeted in future studies.

A second possible explanation for the disagreement is that previously published burial history studies (Nowlan and Barnes, 1987; Williams et al., 1998; Cooper et al., 2001) may have underestimated the maximum burial temperatures to which the St George Group dolomites were exposed. However, because of their potential as hydrocarbon reservoirs, the Lower Ordovician rocks of western Newfoundland have been studied extensively (e.g., Nowlan and Barnes, 1987; Williams et al., 1998; Cooper et al., 2001; Azmy et al., 2008; Azmy et al., 2009; Azmy and Conliffe, 2010; Azomani et al., 2013; Olanipekun et al., 2014; many others), and previously published burial history investigations include results from conodont alteration index, acritarch alteration indices, and graptolite reflectance (Nowlan and Barnes, 1987; Williams et al., 1998; Cooper et al., 2001). If burial temperatures did exceed $\sim 250^{\circ} \mathrm{C}$ (the temperature above which solid-state isotope exchange reactions occur in dolomite according to Lloyd and Eiler, 2014) then 
the previous work suggesting maximum temperatures of $\sim 160^{\circ} \mathrm{C}$ (Nowlan and Barnes, 1987; Williams et al., 1998; Cooper et al., 2001) were considerable underestimates.

A third possible explanation is that we underestimate precipitation temperatures for some of our dolomites, specifically, for the D1 samples from the Boat Harbour formation and the D2 sample from the Aguathuna formation. In the case of the D1 Boat Harbour samples, the fabricretentive textures (e.g., algal lamination), near-micritic grain sizes (Figure 2B), and insignificant re-crystallization provide potential evidence that they formed at near-surface conditions of temperatures below $50{ }^{\circ} \mathrm{C}$ (Olanipekun et al., 2014; cf. Gradstein and Reynolds, 1994). A caveat is that recrystallization can occur on an atom by atom scale and thus be fabric retentive, which could possibly be tested using novel approaches that can identify small-scale structural or chemical changes, such as high-spatial resolution techniques (e.g., synchrotron, atom probe, secondary ion mass spectrometry, electron probe mapping). Nonetheless, if recrystallization of the D1 Boat Harbour samples did occur at temperatures in excess of $\sim 100{ }^{\circ} \mathrm{C}$ (see Table 3 for temperatures predicted by various calibration equations) then it would appear that it did not impact these petrographic features. In the case of the D2 Aguathuna sample, the fluid inclusions were primary, as described in Section 6.1.1 above, and should therefore reflect the temperature at which the enclosing mineral phase precipitated. It is conceivable that some undetectable reequilibration occurred in the measured inclusions, but repeated $\mathrm{T}_{h}$ measurements of D2 dolomites from throughout the Aguathuna formation provide very consistent results $\left(\mathrm{T}_{h}=73.2 \pm\right.$ $3.5^{\circ} \mathrm{C}$; Table 1 ), which suggests that re-equilibration is unlikely.

\subsection{The $\Delta_{47}$ to temperature relationship in the St. George Group dolomites}


In the discussion that follows, only $\Delta_{47}$ data from samples that did not exhibit obvious evidence of modification as described in Section 6.1.2 above are included (i.e. D1 dolomites from Boat Harbour, D2 dolomites from Aguathuna, and D2 dolomites from Catoche are not included). We stress, however, that any or all of the samples in our suite may have experienced some degree of solid-state reordering, in which case the $\Delta_{47}$ at the time of precipitation and entrapment of the fluid inclusions would have been greater than our measured $\Delta_{47}$. Therefore, the relationship between temperature and $\Delta_{47}$ presented here should not be considered a true "calibration."

A linear least squares regression of the $\Delta_{47}$ values of the St. George Group dolomites plotted vs. $10^{6} / \mathrm{T}^{2}$ (where $\mathrm{T}$ is $\mathrm{T}_{h}$ expressed in Kelvin) yields:

$$
\begin{aligned}
& \Delta_{47}=(0.0434 \pm 0.0510) * 10^{6} / \mathrm{T}^{2}+(0.2086 \pm 0.3161) \\
& \left(\mathrm{n}=6 ; \mathrm{R}^{2}=0.58 ; \mathrm{SE}_{\mathrm{est}}=0.0286 ; 95 \% \mathrm{CI}\right)
\end{aligned}
$$

where $\Delta_{47}$ is expressed in the absolute reference frame of Dennis et al. (2011).

\subsection{Possible implications for discrepant calibrations}

As described in Section 1, many of the previously published $\Delta_{47}$ to temperature relationships lie in one of two main clusters: one cluster that resembles the equation initially derived by the group at Caltech (Ghosh et al., 2006a; Ghosh et al., 2007; Tripati et al., 2010, 2015; Thiagarajan

et al., 2011; Grauel et al., 2013; Zaarur et al., 2013; Came et al., 2014; Kimball et al., 2015); and a second cluster that resembles an equation derived by the group at Harvard (Dennis and Schrag, 
2010; Tang et al., 2014; Wacker et al., 2014; Defliese et al., 2015; Kimball et al., 2015; Kluge et al., 2015). Several possible explanations for these apparent calibration differences have been explored, such as the acid digestion fractionation factor (Defliese et al., 2015), sample size (Wacker et al., 2013), a sensitivity of phosphoric acid fractionation to the bulk or clumped isotopic compositions of carbonates (Wacker et al., 2014), differences in the procedures utilized by laboratories (e.g., Henkes et al., 2013; Came et al., 2014; Fernandez et al., 2014; Wacker et al., 2014; Defliese et al., 2015), kinetic isotope effects (Hill et al., 2014a; Tripati et al., 2015), and/or the substitution of different cations in the mineral lattice (Hill et al., 2014b; Yuan, 2015). Confidently determining the nature of the origin of these discrepancies is beyond the scope of the present work. However, because the various calibration equations diverge at high temperatures (see Figure 6), calibration data from samples that precipitated in relatively high temperature environments $\left(\sim 73\right.$ to $\left.176^{\circ} \mathrm{C}\right)$ may contribute to our understanding of these issues.

Figure 6A provides a comparison of the $\Delta_{47}$ results from the St. George Group dolomites to several published empirical calibrations, which for consistency, are all presented in the absolute reference frame (ARF; Dennis et al., 2011) and converted to $25^{\circ} \mathrm{C}$ using the acid fractionation factors of Defliese et al. (2015), assuming no mineral-specific differences. For the sake of clarity, only a select subset of the published $\Delta_{47}$ to temperature relationships are included in Figure 6A: 1) a compilation of calibration data from high temperature acid digestions (Defliese et al., 2015); 2) a compilation of calibration data from $25^{\circ} \mathrm{C}$ acid digestions (Zaarur et al., 2013); 3) a single comprehensive calibration study that includes calibration samples that precipitated in high temperature environments (25 to $250{ }^{\circ} \mathrm{C}$; Kluge et al., 2015); 4) a theoretical equation for calcite (Schauble et al., 2006) incorporating an intercept of 0.268 (Guo et al., 2009); 5) a second theoretical equation for calcite (Hill et al., 2014a) also incorporating an intercept of 0.268 (Guo 
et al., 2009); and 6) several high temperature (475 to $\left.1550^{\circ} \mathrm{C}\right)$ data points that were generated using calcites from laboratory heating experiments (Ghosh et al., 2006a; Guo et al., 2009; Passey and Henkes, 2012; Stolper and Eiler, 2015). The calibration of Defliese et al. (2015) is plotted as the authors present it in their Equation 6. Their equation was derived using their own data as well as a compilation of previously published calibration data (all digested at $70{ }^{\circ} \mathrm{C}$ or greater), which they readjusted to $25^{\circ} \mathrm{C}$ using their new acid fractionation factor. The Defliese et al. (2015) study incorporates data from the following: Eagle et al. (2010), Dennis \& Schrag (2010), Dennis et al. (2013), Eagle et al. (2013), Henkes et al. (2013), Fernandez et al. (2014), and Tang et al. (2014). The calibration of Kluge et al. (2015) is plotted as we recalculated it after adjusting the data (which the authors generated using reaction temperatures of both 70 and $90{ }^{\circ} \mathrm{C}$ ) using the acid fractionation factors of Defliese et al. (2015) and performing a least squares linear regression:

$\Delta_{47}=(0.0388 \pm 0.0011) * 10^{6} / \mathrm{T}^{2}+(0.2652 \pm 0.0092)$

$\left(n=26 ; R^{2}=0.98 ; \mathrm{SE}_{\mathrm{est}}=0.0126 ; 95 \% \mathrm{CI}\right)$.

The calibration of Zaarur et al. (2013) is plotted as the authors present it in their Equation 7. It includes the authors' calibration data from synthetic carbonates as well as calibration data from the synthetic carbonates of Ghosh et al. (2006a). No acid fractionation correction was performed on the Zaarur et al. (2013) data because all carbonates used their study were reacted in phosphoric acid at $25^{\circ} \mathrm{C}$.

Figure 6A also includes previously published calibration results from studies conducted in the Tripati laboratory at UCLA using the same instrumentation that was used in the present 
study. All samples were digested at $90^{\circ} \mathrm{C}$ in a common acid bath system, eliminating differences in digestion apparatus, temperature, and constants used in calculations as potential sources of uncertainty. Included in Figure 6A are: 1) calibration data from synthetic carbonates that were grown at variable temperature, $\mathrm{pH}$, growth rate, and ionic strength, and analyzed both in the Tripati laboratory and at Tulane University, with both labs yielding statistically indistinguishable results (Tang et al., 2014); and 2) a dataset for calcite that was grown at variable temperature and with and without an enzyme that catalyzes equilibrium between dissolved inorganic carbon species present (Tripati et al., 2015).

There are several caveats to consider when comparing our new dolomite results to previously published calibrations. First, the measured $\Delta_{47}$ values of the St. George Group dolomites may be lower than the $\Delta_{47}$ at the time of precipitation and entrapment of the fluid inclusions due to possible subsequent heating and solid-state reordering. Second, the potential impact of recrystallization on an atom-by-atom scale can not be determined confidently without further work. Thus, given the uncertainty of what the $\Delta_{47}$ values of the dolomites actually reflect (formation, recrystallization, re-ordering), it is premature to declare that they are most consistent with a particular calibration line. Third, if there are mineral-specific acid digestion fractionation factors as has been suggested by Murray et al. (2016), then our results would be substantially offset, as shown in Figure 6B. Finally, the magnesium content of carbonate minerals in the calcite-dolomite solid solution is predicted from theory to exert a significant and measurable effect on $\Delta_{47}$ (Hill et al, 2014b), which is supported by recent observations from high-Mg deepsea coral (Kimball et al., 2015).

With these caveats, we find that a regression through the dolomite data as described in Equation 1 is consistent with the theoretical relationship for calcite (Schauble et al., 2006; Guo et 
al., 2009; Passey and Henkes, 2012), and with the shallow slope cluster of calibrations, if the errors in our regression are not taken into account (Figure 6A). We note that although the slope of this equation is very similar to the slopes of the equations generated by Dennis et al. (2010), Tang et al. (2014), Kluge et al. (2015), Wacker et al. (2014), Defliese et al. (2015), and Kimball et al., (2015), the error bounds in our calibration are substantially greater. It is also important to note that the scatter in our data set and the small number of samples in our suite result in a poor coefficient of determination $\left(R^{2}=0.58\right)$ and a wide $95 \%$ confidence interval (Figure 6A), and therefore it is possible that the similarity between our results and the previously published results supporting a shallow calibration slope is fortuitous. Hence, our results do not preclude the steeper slopes reported by Ghosh et al., 2006a, Ghosh et al., 2007, Tripati et al., 2010, 2015, Thiagarajan et al., 2011; Grauel et al., 2013, Zaarur et al., 2013, and Came et al., 2014.

\section{CONCLUSIONS}

In summary, our new $\Delta_{47}$ results provide new constraints on the clumped isotope compositions of dolomites that precipitated in environments of $\sim 73$ to $176^{\circ} \mathrm{C}$, and they lay further groundwork for future applications of this proxy to a range of investigations involving dolomites from sub-surface environments. If we assume that calcite and dolomite have the same acid digestion fractionation factor (Defliese et al, 2015), which has been recently challenged (Murray et al., 2016), then over the temperature range of $\sim 73$ to $176^{\circ} \mathrm{C}$, our results are consistent with the theoretical relationship for calcite (Schauble et al., 2006; Guo et al., 2009). Our findings do not exclude the approach of previous authors who used the theoretical equation to determine the precipitation temperatures of diagenetic dolomites (e.g., Budd et al., 2013; Ferry et al., 2011; 
Bristow et al., 2011; Loyd et al., 2012; Dale et al., 2014). However, our data are also within error of a range of published calibrations when those calibrations are extrapolated to high temperatures.

We confirm the results of previous authors (e.g., Ghosh et al., 2006a; Guo et al., 2009; Dennis and Schrag, 2010; Ferry et al., 2011; Bristow et al., 2011; Loyd et al., 2012; Passey and Henkes, 2012; Budd et al., 2013; Dale et al., 2014; Henkes et al., 2014; Lloyd and Eiler, 2014; Stolper and Eiler, 2015; Tripati et al., 2015) who through heating experiments or studies of fieldcollected samples found that the $\Delta_{47}$ signatures of carbonates from near-surface conditions can be reset by diagenetic processes. Notably, our results imply that the susceptibility of the mineral dolomite to thermally activated solid-state isotope exchange may be greater than estimated previously (Eiler, 2011; Lloyd and Eiler, 2014; Ferry et al., 2011). We suggest that $\Delta_{47}$ thermometry has the potential to provide valuable insights when paired with fluid inclusion microthermometry to determine both the temperature at which a sedimentary carbonate formed $\left(\mathrm{T}_{h}\right)$ and a higher temperature to which it was subsequently exposed $\left(\Delta_{47}\right)$, thereby providing critical information for determining whether a given formation may have been exposed to temperatures within the oil or gas "windows".

\section{ACKNOWLEDGEMENTS}

Work was supported by UNH startup funds, by NSF OCE-1260350, Department of Energy BES grant DE-FG02-13ER16402 and by PEEP (Petroleum Exploration Enhancement Program, Newfoundland, Canada). We thank the members of the Tripati clumped isotope laboratory at 
UCLA for technical support. We are grateful to H. Affek, M. Hren, and two anonymous reviewers who provided thoughtful feedback that improved this work appreciably.

\section{FIGURE CAPTIONS}

Figure 1. A map of the study area showing the locations of sampled outcrops and cores, which represent the Lower Ordovician St. George Group carbonates in western Newfoundland, Canada (Knight, 2008; Azomani et al., 2013).

Figure 2. (A) A diagram showing the stratigraphic framework of the St. George Group carbonates from which the samples were collected (Knight, 2008; Azmy et al., 2009). Photomicrographs showing the petrographic characteristics of: (B) the D1 dolomicrite; and (C) the D2 (sub- to euhedral zoned) and D3 latest anhedral saddle dolomite.

Figure 3. Previously published fluid inclusion temperatures $\left(\mathrm{T}_{h}\right)$ of dolomite cements (Azmy et al., 2008; Azmy et al., 2009; Conliffe et al., 2009; Azmy and Conliffe, 2010; Azomani et al., 2013; Olanipekun et al., 2014) and newly acquired oxygen isotopic measurements. (A) Mean $\delta^{18} \mathrm{O}_{\mathrm{d}}(\mathrm{PDB})$ plotted versus $\mathrm{T}_{h}$; (B) calculated $\delta^{18} \mathrm{O}_{\mathrm{w}}(\mathrm{SMOW})$ versus $\mathrm{T}_{h}$. The $\delta{ }^{18} \mathrm{O}_{\mathrm{w}}$ values were calculated using $\delta^{18} \mathrm{O}_{\mathrm{d}}$, the previously published $\mathrm{T}_{h}$ values, and the equation of Horita (2014). Contours of $\delta^{18} \mathrm{O}_{\mathrm{d}}$ are derived from a published calibration for dolomite (Horita, 2014). Error bars in (A) represent 1 standard deviation on $\mathrm{T}_{h}$ and $\delta^{18} \mathrm{O}_{\mathrm{d}}$. Shaded error spaces in $(\mathbf{B})$ represent the $1 \sigma$ range of possible $T_{h}$ values and the $1 \sigma$ uncertainty in $\delta^{18} \mathrm{O}$ propagated through the calibration equation. Open circles represent D1; "x" symbols represent D2; filled diamonds 
represent D3. Black symbols represent data from the Boat Harbour formation; green symbols represent data from the Catoche formation; red symbols represent data from the Aguathuna formation. The $50{ }^{\circ} \mathrm{C}$ values for D1 samples represent maximum temperatures (see Section 3.2).

Figure 4. The relationship between the $\Delta_{47}$ of dolomites (this study) and previously published fluid inclusion temperatures $\left(\mathrm{T}=\mathrm{T}_{h}\right)$. Dolomites were reacted at $90{ }^{\circ} \mathrm{C}$, and $\Delta_{47}$ values were converted to $25^{\circ} \mathrm{C}$ using a correction of $0.082 \%$ (Defliese et al., 2015). All $\Delta_{47}$ data are reported on the absolute reference frame (ARF) of Dennis et al. (2011). Error bars on $\Delta_{47}$ represent the standard error of replicate measurements (1 SE). Error bars on temperature values $\left(\mathrm{T}_{h}\right)$ represent 1 standard deviation $(1 \sigma)$. Open circles represent D1; "x" symbols represent D2; filled diamonds represent D3. Black symbols represent data from the Boat Harbour formation; green symbols represent data from the Catoche formation; red symbols represent data from the Aguathuna formation. The $50^{\circ} \mathrm{C}$ values for D1 samples represent maximum temperatures (see Section 3.2). The dotted purple line represents the theoretical calcite relationship as determined by Schauble et al. (2006) with the intercept of Guo et al. (2009) transferred to the absolute reference frame using the transfer function of Dennis et al. (2011).

Figure 5. The relationship between the temperatures derived from fluid inclusion microthermometry $\left(\mathrm{T}_{h}\right)$ (Azmy et al., 2008; Azmy et al., 2009; Conliffe et al., 2009; Azmy and Conliffe, 2010; Azomani et al., 2013; Olanipekun et al., 2014) and the $\Delta_{47}$ temperatures as determined using the theoretical calcite relationship of Schauble et al. (2006) with the intercept of Guo et al. (2009) transferred to the absolute reference frame using the transfer function of Dennis et al. (2011). Open circles represent D1; "x" symbols represent D2; filled diamonds 
represent D3. Black symbols represent data from the Boat Harbour formation; green symbols represent data from the Catoche formation; red symbols represent data from the Aguathuna formation. The $50{ }^{\circ} \mathrm{C}$ values for D1 samples represent maximum temperatures (see Section 3.2). Error bars on fluid inclusions temperature represent 1 standard deviation $(1 \sigma)$. Error bars on $\Delta_{47}$ temperatures represent $1 \mathrm{SE}$ uncertainty in $\Delta_{47}$ propagated through the calibration equation. The black line represents a 1:1 relationship.

Figure 6. A comparison of $\Delta_{47}$ data from dolomites (this study) to published calcite calibrations. (A) Data corrected using the phosphoric acid fractionation factor of Defliese et al. (2015). The dotted purple line represents the theoretical calcite relationship of Schauble et al. (2006) with the intercept of Guo et al. (2009) transferred to the absolute reference frame using the transfer function of Dennis et al. (2011). The solid purple line represents the theoretical calcite relationship of Hill et al. (2014a) with the intercept of Guo et al. (2009) transferred to the absolute reference frame using the transfer function of Dennis et al. (2011). The green line represents the calibration of Defliese et al. (2015), which includes calibration data from their study as well as calibration data from previous studies. Data included in the Defliese et al. (2015) compilation are: Eagle et al. (2010), Dennis \& Schrag (2010), Dennis et al. (2013), Eagle et al. (2013), Henkes et al. (2013), Fernandez et al. (2014), and Tang et al. (2014). The orange line represents a least squares linear regression through the synthetic calibration data of Kluge et al. (2015), which we recalculated using the acid fractionation factor of Defliese et al. (2015). The red line represents the calibration of Zaarur et al. (2013), which includes their calibration data from synthetic carbonates as well as calibration data from the synthetic carbonates of Ghosh et al. (2006a). The dashed red line represents an extrapolation of the Zaarur et al. (2013) equation 
to precipitation temperatures beyond the scope of the authors' sample suite. The blue line represents the calibration of Tang et al. (2014), which we modified to reflect the acid fractionation factor of Defliese et al. (2015). The brown line represents the calibration of Tripati et al. (2015), which we modified to reflect the acid fractionation factor of Defliese et al. (2015). Open triangles (Stolper and Eiler, 2015), open squares (Passey and Henkes, 2012), the open diamond (Ghosh et al., 2006a) and the open circle (Guo et al., 2009) represent data from calcites used in heating experiments. All dolomite samples from the present study were reacted at $90{ }^{\circ} \mathrm{C}$, and values were converted to $25^{\circ} \mathrm{C}$ using a correction of $0.082 \%$ (Defliese et al., 2015). Error bars on $\Delta_{47}$ represent the standard error of replicate measurements (1 SE). Error bars on temperature $\left(\mathrm{T}_{h}\right)$ values represent 1 standard deviation $(1 \sigma)$. Black filled diamonds represent samples from our suite that did not show obvious evidence of solid-state reordering as described in Section 6.1.2; crosses represent samples that did show evidence of solid-state reordering as described in Section 6.1.2. The black line represents a least squares linear regression using the St. George Group data that did not show evidence of solid-state reordering. The dashed black lines represent the $95 \%$ confidence interval on that regression. All $\Delta_{47}$ data are reported on the absolute reference frame (ARF) of Dennis et al. (2011). (B) As in (A), except with the dolomite data from the present study corrected using the phosphoric acid fractionation factor of Murray et al. (2016).

\section{REFERENCES}

Affek H. and Eiler J. (2006) Abundance of mass $47 \mathrm{CO}_{2}$ in urban air, car exhaust, and human breath. Geochim. Cosmochim. Acta 70, 1-12. 
Affek H. P., Bar-Matthews M., Ayalon A., Matthews A. and Eiler J. M. (2008)

Glacial/interglacial temperature variations in Soreq cave speleothems as recorded by “clumped isotope" thermometry. Geochim. Cosmochim. Acta 72, 5351-5360.

Azmy K. and Conliffe J. (2010) Dolomitization of the lower St. George Group on the Northern Peninsula in western Newfoundland: implications for lateral distribution of porosity. Bull. Can. Pet. Geol. 58, 361-374.

Azmy K., Knight I., Lavoie D. and Chi G. (2009) Origin of dolomites in the Boat Harbour Formation, St. George Group, in western Newfoundland, Canada: Implications for porosity development. Bull. Can. Pet. Geol. 57, 81-104.

Azmy K., Lavoie D., Knight I. and Chi G. (2008) Dolomitization of the Lower Ordovician Aguathuna Formation carbonates, Port au Port Peninsula, western Newfoundland, Canada: implications for a hydrocarbon reservoir. Can. J. Earth Sci. 45, 795-813.

Azomani E., Azmy K., Blamey N., Brand U. and Al-Aasm I. (2013) Origin of Lower Ordovician dolomites in eastern Laurentia: Controls on porosity and implications from geochemistry. Mar. Pet. Geol. 40, 99-114.

Barker C. E. and Goldstein R. H. (1990) Fluid inclusion technique for determining maximum temperature in calcite and its comparison to the vitrinite reflectance geothermometer. Geology 18, 1003-1006.

Bodnar R. J. (2003a) Introduction to fluid inclusions. In Fluid Inclusions: Analysis and Interpretation (eds. I. Samson, A. Anderson, and D. Marshall). Mineralogical Association of Canada Short Course 32. 
Bodnar R. J. (2003b) Reequilibration of fluid inclusions. In Fluid Inclusions: Analysis and Interpretation (eds. I. Samson, A. Anderson, and D. Marshall). Mineralogical Association of Canada Short Course 32.

Bonifacie M., Ferry J. M., Horita J., Vasconcelos C., Passey B. H. and Eiler J. M. (2011) Calibration and applications of the dolomite clumped isotope thermometer to high temperatures. Mineralogical Magazine 75, 551.

Brand U., Posenato R., Came R., Affek H., Angiolini L., Azmy K. and Farabegoli E. (2012) The end - Permian mass extinction: A rapid volcanic $\mathrm{CO}_{2}$ and $\mathrm{CH}_{4}$-climatic catastrophe. Chem. Geol. 322-3, 121-144.

Bristow T. F., Bonifacie M., Derkowski A., Eiler J. M. and Grotzinger J. P. (2011) A hydrothermal origin for isotopically anomalous cap dolostone cements from south China. Nature 474, 68-71.

Budd D. A., Frost E. L. III, Huntington K. W. and Allwardt P. F. (2013) Syndepositional deformation features in high-relief carbonate platforms: Long-lived conduits for diagenetic fluids. J. Sed. Res. 83, 12-38.

Came R. E., Brand U. and Affek H. P. (2014) Clumped isotope signatures in modern brachiopod carbonate. Chem. Geol. 377, 20-30.

Came R. E., Eiler J. M., Veizer J., Azmy K., Brand U. and Weidman C. R. (2007) Coupling of surface temperatures and atmospheric $\mathrm{CO}_{2}$ concentrations during the Palaeozoic era. Nature 449, 198-201.

Clark I. D. and Fritz P. (1997) Environmental Isotopes in Hydrogeology, Taylor \& Francis, CRC Press. 
Conliffe J., Azmy K., Knight I. and Lavoie D. (2009) Dolomitization of the Lower Ordovician Watts Bight Formation of the St. George Group, western Newfoundland: evidence of hydrothermal fluid alteration. Can. J. Earth Sci. 46, 247-261.

Cooper M., Weissenberger J., Knight I., Hostad D., Gillespie D., Williams H., Burden E., PorterChaudhry J., Rae D. and Clark E. (2001) Basin evolution in western Newfoundland: New insights from hydrocarbon exploration. AAPG Bull. 85, 393-418.

Csank A. Z., Tripati A. K., Patterson W. P., Eagle R. A., Rybczynski N., Ballantyne A. P. and Eiler J. M. (2011) Estimates of Arctic land surface temperatures during the early Pliocene from two novel proxies. Earth Planet. Sci. Lett. 304, 291-299.

Daëron M., Guo W., Eiler J., Genty D., Blamart D., Boch R., Drysdale R., Maire R., Wainer K. and Zanchetta G. (2011) ${ }^{13} \mathrm{C}^{18} \mathrm{O}$ clumping in speleothems: Observations from natural caves and precipitation experiments. Geochim. Cosmochim. Acta 75, 3303-3317.

Dale A., John C. M., Mozley P. S., Smalley P. C. and Muggeridge A. H. (2014) Time-capsule concretions: Unlocking burial diagenetic processes in the Mancos Shale using carbonate clumped isotopes. Earth Planet. Sci. Lett. 394, 30-37.

Defliese W. F., Hren M. T. and Lohmann K. C. (2015) Compositional and temperature effects of phosphoric acid fractionation on $\Delta_{47}$ analysis and implications for discrepant calibrations. Chem. Geol. 396, 51-60.

Dennis K. J., Affek H. P., Passey B. H., Schrag D. P. and Eiler J. M. (2011) Defining an absolute reference frame for "clumped" isotope studies of $\mathrm{CO}_{2}$. Geochim. Cosmochim. Acta 75, 71177131.

Dennis K. J. and Schrag D. P. (2010) Clumped isotope thermometry of carbonatites as an indicator of diagenetic alteration. Geochim. Cosmochim. Acta 74, 4110-4122. 
Douglas P. M. J., Affek H. P., Ivany L. C., Houben A. J. P., Sijp W. P., Sluijs A., Schouten S. and Pagani M. (2014) Pronounced zonal heterogeneity in Eocene southern high-latitude sea surface temperatures. Proc. Natl. Acad. Sci. 11, 6582-6587.

Eagle R. A., Eiler J. M., Tripati A. K., Ries J. B., Freitas P. S., Hiebenthal C., Wanamaker Jr A. D., Taviani M., Elliot M. and Marenssi S. (2013) The influence of temperature and seawater carbonate saturation state on ${ }^{13} \mathrm{C}-{ }^{18} \mathrm{O}$ bond ordering in bivalve mollusks. Biogeosciences $\mathbf{1 0}$, $157-194$.

Eagle R. A., Risi C., Mitchell J. L., Eiler J. M., Seibt U., Neelin J. D., Li G. and Tripati A. K. (2013) High regional climate sensitivity over continental China constrained by glacial-recent changes in temperature and the hydrological cycle. Proc. Natl. Acad. Sci. 110, 8813-8818.

Eagle R. A., Schauble E. A., Tripati A. K., Tütken T., Hulbert R. C. and Eiler J. M. (2010) Body temperatures of modern and extinct vertebrates from ${ }^{13} \mathrm{C}-{ }^{18} \mathrm{O}$ bond abundances in bioapatite. Proc. Natl. Acad. Sci. 107, 10377-10382.

Eagle R. A., Tütken T., Martin T. S., Tripati A. K., Fricke H. C., Connely M., Cifelli R. L. and Eiler J. M. (2011) Dinosaur body temperatures determined from isotopic $\left({ }^{13} \mathrm{C}-{ }^{18} \mathrm{O}\right)$ ordering in fossil biominerals. Science 333, 443-445.

Farley K. A. (2002) (U-Th)/He Dating: Techniques, calibrations, and applications. Rev. Mineral. Geochem. 47, 819-844.

Fernandez A., Tang J. and Rosenheim B. E. (2014) Siderite "clumped" isotope thermometry: A new paleoclimate proxy for humid continental environments. Geochim. Cosmochim. Acta 126, $411-421$. 
Ferry J. M., Passey B. H., Vasconcelos C. and Eiler J. M. (2011) Formation of dolomite at 40-80

${ }^{\circ} \mathrm{C}$ in the Latemar carbonate buildup, Dolomites, Italy, from clumped isotope thermometry. Geology 39, 571-574.

Finnegan S., Bergmann K., Eiler J. M., Jones D. S., Fike D. A., Eisenman I., Hughes N. C., Tripati A. K. and Fischer W. W. (2011) The magnitude and duration of Late OrdovicianEarly Silurian glaciation. Science 331, 903-906.

Garzione C. N., Hoke G. D., Libarkin J. C., Withers S., MacFadden B., Eiler J., Ghosh P. and Mulch A. (2008) Rise of the Andes. Science 320, 1304-1307.

Ghosh P., Adkins J., Affek H., Balta B., Guo W., Schauble E. A., Schrag D. and Eiler J. M. (2006a) ${ }^{13} \mathrm{C}^{-18} \mathrm{O}$ bonds in carbonate minerals: A new kind of paleothermometer. Geochim. Cosmochim. Acta 70, 1439-1456.

Ghosh P., Eiler J., Campana S. E. and Feeney R. F. (2007) Calibration of the carbonate "clumped isotope" paleothermometer for otoliths. Geochim. Cosmochim. Acta 71, 2736-2744.

Ghosh P., Garzione C. N. and Eiler J. M. (2006b) Rapid uplift of the Altiplano revealed through ${ }^{13} \mathrm{C}-{ }^{18} \mathrm{O}$ bonds in paleosol carbonates. Science $\mathbf{3 1 1}, 511-515$.

Gleadow A. J. W., Duddy I. R., Green P. F. and Lovering J. F. (1986) Confined fission track lengths in apatite: a diagnostic tool for thermal history analysis. Contrib. Mineral. Petrol. 94, $405-415$.

Goldstein, R.H., 2003. Petrographic analysis of fluid inclusions. In Fluid Inclusions: Analysis and Interpretation (eds. I. Samson, A. Anderson, and D. Marshall). Mineralogical Association of Canada Short Course 32.

Goldstein R. H. and Reynolds, T.J. (1994) Systematics of fluid inclusions in diagenetic minerals, SEPM, Tulsa, OK. 
Grauel A.-L., Schmid T. W., Hu B., Bergami C., Capotondi L., Zhou L. and Bernasconi S. M. (2013) Calibration and application of the "clumped isotope" thermometer to foraminifera for high-resolution climate reconstructions. Geochim. Cosmochim. Acta. 108, 125-140.

Guo W. and Eiler J. (2007) Temperatures of aqueous alteration and evidence for methane generation on the parent bodies of the CM chondrites. Geochim. Cosmochim. Acta 71, 55655575.

Guo W., Mosenfelder J. L., Goddard III W. A. and Eiler J. M. (2009) Isotopic fractionations associated with phosphoric acid digestion of carbonate minerals: insights from firstprinciples theoretical modeling and clumped isotope measurements. Geochim. Cosmochim. Acta 73, 7203-7225.

Halevy I., Fischer W. W. and Eiler J. M. (2011) Carbonates in the Martian meteorite Allan Hills 84001 formed at $18 \pm 4{ }^{\circ} \mathrm{C}$ in a near-surface aqueous environment. Proc. Natl. Acad. Sci. 108, $16895-16899$.

Henkes G. A., Passey B. H., Grossman E. L., Shenton B. J., Pérez-Huerta A. and Yancey T. E. (2014) Temperature limits for preservation of primary calcite clumped isotope paleotemperatures. Geochim. Cosmochim. Acta 139, 362-382.

Henkes G. A., Passey B. H., Wanamaker Jr. A. D., Grossman E. L., Ambrose Jr. W. G. and Carroll M. L. (2013) Carbonate clumped isotope compositions of modern marine mollusk and brachiopod shells. Geochim. Cosmochim. Acta 106, 307-325.

Hill P., Tripati A. and Schauble E. (2014a) Theoretical constraints on the effects of pH, salinity, and temperature on clumped isotope signatures of dissolved inorganic carbon species and carbonate minerals. Geochim. Cosmochim. Acta 125, 610-652. 
Hill, P.S., Tripati, A. and Schauble, E.A. (2014b) Predicting effects of cations (Mg, Ca, Na, and $\mathrm{K})$ on ${ }^{13} \mathrm{C}-{ }^{18} \mathrm{O}$ clumping in dissolved inorganic carbon species and implications for carbonate geothermometry. AGU Fall Meeting Abstracts.

Horita J. (2014) Oxygen and carbon isotope fractionation in the system dolomite-water- $\mathrm{CO}_{2}$ to elevated temperatures. Geochim. Cosmochim. Acta 129, 111-124.

Huntington K. W., Budd D. A., Wernicke B. P. and Eiler J. M. (2011) Use of clumped-isotope thermometry to constrain the crystallization temperature of diagenetic calcite. J. Sediment. Res. 81, 656-669.

Huntington K. W., Eiler J. M., Affek H. P., Guo W., Bonifacie M., Yeung L. Y., Thiagarajan N., Passey B., Tripati A. and Daëron M. (2009) Methods and limitations of "clumped" $\mathrm{CO}_{2}$ isotope $\left(\Delta_{47}\right)$ analysis by gas-source isotope ratio mass spectrometry. J. Mass Spectrom. 44, $1318-1329$.

Huntington K., Wernicke B. and Eiler J. (2010) The influence of climate change and uplift on Colorado Plateau paleotemperatures from carbonate clumped-isotope thermometry. Tectonics 29, TC3005, doi:10.1029/2009TC002449.

James N. P., Stevens R. K., Barnes C. R., and Knight I. (1989) Evolution of a Lower Paleozoic continental-margin carbonate platform, northern Canadian Appalachians. In Controls on Carbonate Platform and Basin Development, Special Publication 44 (ed. P. D. Crevello, J. L. Wilson, J. F. Sarg, and J. F. Read), pp. 123-146. Society of Economic Paleontologists and Mineralogists.

Keating-Bitonti C. R., Ivany L. C., Affek H. P., Douglas P. and Samson S. D. (2011) Warm, not super-hot, temperatures in the early Eocene subtropics. Geology 39, 771-774. 
Kimball, J., Eagle, R.T. and Dunbar, R. (2015) Carbonate "clumped" isotope signatures in aragonitic scleractinian and calcitic gorgonian deep-sea corals. Biogeosciences Discuss. 12(23), 19115-19165.

Kluge T., Affek H. P., Dublyansky Y. and Spötl C. (2014) Devils Hole paleotemperatures and implications for oxygen isotope equilibrium fractionation. Earth Planet. Sci. Lett. 400, 251260.

Kluge T., John C. M., Jourdan A.-L., Davis S. and Crawshaw J. (2015) Laboratory calibration of the calcium carbonate clumped isotope thermometer in the $25-250{ }^{\circ} \mathrm{C}$ temperature range. Geochim. Cosmochim. Acta 157, 213-227.

Knight I. and James N. P. (1987) The stratigraphy of the Lower Ordovician St. George Group, western Newfoundland: the interaction between eustasy and tectonics. Can. J. Earth Sci. 24, 1927-1951.

Knight I., Azmy K., Boyce D. and Lavoie D. (2008) Tremadocian carbonates of the lower St. George Group, Port au Port Peninsula, western Newfoundland: Lithostratigraphic setting of diagenetic, isotopic, and geochemistry studies. In Current Research Report 08-1 (ed. C. P. G. Pereira and D. G. Walsh), pp. 115-149. Newfoundland and Labrador Department of Natural Resources Geological Survey.

Lloyd M. K. and Eiler J. M. (2013) Laboratory and Natural Constraints on the Temperature Limit for Preservation of the Dolomite Clumped Isotope Thermometer, Abstract \#V11A4694 presented at American Geophysical Union, Fall Meeting 2014, San Francisco, CA, 1519 December. 
Loyd S. J., Corsetti F. A., Eiler J. M. and Tripati A. K. (2012) Determining the Diagenetic Conditions of Concretion Formation: Assessing Temperatures and Pore Waters Using Clumped Isotopes. J. Sed Res. 82, 1006-1016.

Loyd S. J., Dickson J. A. D., Scholle P. A. and Tripati A. K. (2013) Extensive, uplift-related and non-fault-controlled spar precipitation in the Permian Capitan Formation. Sediment. Geol. 298, 17-27.

Murray, S.T., Arienzo, M.M. and Swart, P.K. (2016) Determining the $\Delta_{47}$ acid fractionation in dolomites. Geochim. Cosmochim. Acta 174, 42-53.

Mussman W. J. and Read J. F. (1986) Sedimentology and development of a passive- to convergent-margin unconformity: Middle Ordovician Knox unconformity, Virginia Appalachians. Geol. Soc. Am. Bull. 97, 282-295.

Nowlan, G.S. and Barnes C.R. (1987) Thermal maturation of Paleozoic strata in Eastern Canada from conodont colour alteration index (CAI) data with implications for burial history, tectonic evolution, hotspot tracks and mineral and hydrocarbon exploration. Geological Survey of Canada Bulletin 367, doi:10.4095/122453.

Olanipekun B.-J., Azmy K. and Brand U. (2014) Dolomites of the Boat Harbour Formation in the Northern Peninsula, western Newfoundland, Canada: Implications for dolomitization history and porosity control. AAPG Bull. 98, 765-791.

Passey B. H. and Henkes G. A. (2012) Carbonate clumped isotope bond reordering and geospeedometry. Earth Planet. Sci. Lett. 351-352, 223-236.

Passey B. H., Levin N. E., Cerling T. E., Brown F. H. and Eiler J. M. (2010) High-temperature environments of human evolution in East Africa based on bond ordering in paleosol carbonates. Proc. Natl. Acad. Sci. 107, 11245-11249. 
Peters K. E., Walters C. C. and Moldowan J. M. (2005) The Biomarker Guide: Volume 1, Biomarkers and Isotopes in the Environment and Human History 2nd Edition. Cambridge University Press, Cambridge England.

Pratt B. R. and James N. P. (1986) The St George Group (Lower Ordovician) of western Newfoundland: tidal flat island model for carbonate sedimentation in shallow epeiric seas. Sedimentology 33, 313-343.

Quade J., Eiler J. M., Daëron M. and Achyuthan H. (2013) The clumped isotope geothermometer in soil and paleosol carbonate. Geochim. Cosmochim. Acta 105, 92-107.

Rosenbaum J. and Sheppard S. M. F. (1986) An isotopic study of siderites, dolomites and ankerites at high temperatures. Geochim. Cosmochim. Acta 50, 1147-1150.

Saenger C., Affek H. P., Felis T., Thiagarajan N., Lough J. M. and Holcomb M. (2012) Carbonate clumped isotope variability in shallow water corals: Temperature dependence and growth-related vital effects. Geochim. Cosmochim. Acta 99, 224-242.

Santrock J., Studley S. A. and Hayes J. M. (1985) Isotopic analyses based on the mass spectrum of carbon dioxide. Anal. Chem. 57, 1444-1448.

Schauble E. A., Ghosh P. and Eiler J. M. (2006) Preferential formation of ${ }^{13} \mathrm{C}-{ }^{18} \mathrm{O}$ bonds in carbonate minerals, estimated using first-principles lattice dynamics. Geochim. Cosmochim. Acta 70, 2510-2529.

Sharp Z. D. and Kirschner D. L. (1994) Quartz-calcite oxygen isotope thermometry: A calibration based on natural isotopic variations. Geochim. Cosmochim. Acta 58, 4491-4501.

Shenton B. J., Grossman E. L., Passey B. H., Henkes G. A., Becker T. P., Laya J. C., PerezHuerta A., Becker S. P. and Lawson M. (2015) Clumped isotope thermometry in deeply 
buried sedimentary carbonates: The effects of bond reordering and recrystallization. GSA Bull. 127, 1036-1051.

Shepherd T. J., Rankin A. H., Alderton D. H. M. (1985) A practical guide to fluid inclusions. Blackie, London.

Siman-Tov S., Affek H. P., Matthews A., Aharonov E. and Reches Z. (2016) Shear heating and clumped isotope reordering in carbonate faults. EPSL 445, 136-145.

Stenzel S. R., Knight I. and James N. P. (1990) Carbonate platform to foreland basin: revised stratigraphy of the Table Head Group (Middle Ordovician), western Newfoundland. Can. J. Earth Sci. 27, 14-26.

Suarez M. B., Passey B. H. and Kaakinen A. (2011) Paleosol carbonate multiple isotopologue signature of active East Asian summer monsoons during the late Miocene and Pliocene. Geology 39, 1151-1154.

Tang J., Dietzel M., Fernandez A., Tripati A. K. and Rosenheim B. E. (2014) Evaluation of kinetic effects on clumped isotope fractionation $\left(\Delta_{47}\right)$ during inorganic calcite precipitation. Geochim. Cosmochim. Acta 134, 120-136.

Thiagarajan N., Adkins J. and Eiler J. (2011) Carbonate clumped isotope thermometry of deepsea corals and implications for vital effects. Geochim. Cosmochim. Acta 75, 4416-4425.

Tripati A., Eagle R., Thiagarajan N., Gagnon A., Bauch H., Halloran P. and Eiler J. (2010) ${ }^{13}$ C${ }^{18} \mathrm{O}$ isotope signatures and "clumped isotope" thermometry in foraminifera and coccoliths. Geochim. Cosmochim. Acta 74, 5697-5717.

Tripati A. K., Sahany S., Pittman D., Eagle R. A., Neelin J. D., Mitchell J. L. and Beaufort L. (2014) Modern and glacial tropical snowlines controlled by sea surface temperature and atmospheric mixing. Nat. Geosci. 7, 205-209. 
Veizer J., Ala D., Azmy K., Bruckschen P., Buhl D., Bruhn F., Carden G. A. F., Diener A., Ebneth S., Godderis Y., Jasper T., Korte C., Pawellek F., Podlaha O. G. and Strauss H. (1999) $87 \mathrm{Sr} / 86 \mathrm{Sr}, \delta^{13} \mathrm{C}$ and $\delta^{18} \mathrm{O}$ evolution of Phanerozoic seawater. Chem. Geol. 161, 5988.

Wacker U., Fiebig J. and Schoene B. R. (2013) Clumped isotope analysis of carbonates: comparison of two different acid digestion techniques. Rapid Commun. Mass Spectrom. 27, $1631-1642$.

Wacker U., Fiebig J., Tödter J., Schöne B. R., Bahr A., Friedrich O., Tütken T., Gischler E. and Joachimski M. M. (2014) Empirical calibration of the clumped isotope paleothermometer using calcites of various origins. Geochim. Cosmochim. Acta 141, 127-144.

Williams S. H., Burden E. T. and Mukhopadhyay P. K. (1998) Thermal maturity and burial history of Paleozoic rocks in western Newfoundland. Can. J. Earth Sci. 35, 1307-1322.

Yuan, J. (2015) Influence of $\mathrm{Mg}^{2+}, \mathrm{Fe}^{2+}$ and $\mathrm{Zn}^{2+}$ cations on ${ }^{13} \mathrm{C}-{ }^{18} \mathrm{O}$ bonds in precipitated aragonite, calcite and dolomite: An ab initio study. Open Journal of Geology 5, 254.

Zaarur S., Olack G. and Affek H. P. (2011) Paleo-environmental implication of clumped isotopes in land snail shells. Geochim. Cosmochim. Acta 75, 6859-6869.

Zaarur S., Affek H. P. and Brandon M. T. (2013) A revised calibration of the clumped isotope thermometer. Earth Planet. Sci. Lett. 382, 47-57. 
Table 1. Stable isotope and fluid inclusion data from St. George Group samples.

\begin{tabular}{|c|c|c|c|c|c|c|c|c|c|c|c|c|c|}
\hline \multirow{2}{*}{$\begin{array}{l}\text { Sample } \\
\text { ID }\end{array}$} & \multirow{2}{*}{ Mineral } & \multirow{2}{*}{ Phase } & \multirow{2}{*}{ Formation } & \multicolumn{4}{|c|}{ Previously published $\mathrm{T}_{h}{ }^{*}$} & \multirow{2}{*}{$\begin{array}{c}\delta^{18} \mathrm{O}_{d} \\
\text { (PDB; \%o) }\end{array}$} & \multirow{2}{*}{$\begin{array}{c}\delta^{18} \mathrm{O}_{\mathrm{d}} \\
1 \sigma\end{array}$} & \multirow{2}{*}{$\begin{array}{c}\Delta_{47}{ }^{* *} \\
(\% \circ ; \text { abs })\end{array}$} & \multirow{2}{*}{$\begin{array}{c}\Delta_{47} \\
1 \mathrm{SE}\end{array}$} & \multirow{2}{*}{$\begin{array}{c}\Delta_{47} \\
\mathrm{n}\end{array}$} & \multirow{2}{*}{$\begin{array}{c}\delta^{18} \mathrm{O}_{w}^{\dagger} \\
\text { (SMOW; \%o) }\end{array}$} \\
\hline & & & & \multicolumn{2}{|c|}{ Sample } & \multicolumn{2}{|c|}{ Entire formation } & & & & & & \\
\hline P184-D3 & D3 & very coarse saddle dolomite & Boat Harbour & 135.9 & 11.2 & 148.0 & 18.9 & -12.39 & 0.12 & 0.445 & 0.012 & 3 & 2.38 \\
\hline 6-216 D3 & D3 & very coarse saddle dolomite & Boat Harbour & 129.4 & 8.5 & 131.1 & 8.0 & -11.97 & 0.05 & 0.437 & 0.006 & 5 & 2.07 \\
\hline 4-86.5 D2 & $\mathrm{D} 2$ & zoned med. coarse dolomite & Catoche & 123.6 & 1.0 & 126.9 & 13.2 & -12.50 & 0.02 & 0.456 & 0.007 & 3 & 5.42 \\
\hline 6-138 D2B & $\mathrm{D} 2$ & zoned med. coarse dolomite & Boat Harbour & 121.3 & 9.4 & 114.0 & 11.0 & -9.75 & 0.21 & 0.509 & 0.003 & 3 & 3.55 \\
\hline R1-116-D2 & $\mathrm{D} 2$ & zoned med. coarse dolomite & Aguathuna & 73.4 & 3.2 & 73.2 & 3.5 & -6.39 & 0.25 & 0.486 & 0.028 & 3 & 1.13 \\
\hline P81-D1 & D1 & dolomicrite & Boat Harbour & - & - & - & - & -6.58 & 0.08 & 0.514 & 0.010 & 3 & -3.05 \\
\hline P92-D1 & D1 & dolomicrite & Boat Harbour & - & - & - & - & -6.77 & 0.14 & 0.530 & 0.010 & 5 & -3.20 \\
\hline
\end{tabular}

${ }^{*} T_{h}$ is previously published homogenization temperature based on fluid-inclusion microthermometry (Azmy et al., 2008; Azomani et al., 2013; Olanipekun et al., 2014). No $T_{h}$ values were obtained for D1 dolomicrites because inclusions were too small, though formation temperatures are reported to be less than $50^{\circ} \mathrm{C}(\mathrm{Olanipekun}$ et al., 2014).

${ }^{* *}$ An acid fractionation correction of $+0.082 \%$ was applied (Defliese et al., 2015).

${ }^{\dagger}$ The isotopic composition of formation water $\left(\delta^{18} \mathrm{O}_{w}\right)$ was calculated using $\mathrm{T}_{h}, \delta^{18} \mathrm{O}_{\mathrm{d}}$, and the equation of Horita (2014). 
Table 2. Standard values for the runs.

\begin{tabular}{|c|c|c|c|c|c|c|c|c|}
\hline $\begin{array}{l}\text { Sample } \\
\text { ID }\end{array}$ & $\begin{array}{c}\delta^{13} \mathrm{C} \\
\text { (PDB; \%o }\end{array}$ & $\begin{array}{c}\delta^{13} \mathrm{C} \\
1 \sigma \\
\end{array}$ & $\begin{array}{c}\delta^{18} \mathrm{O} \text { calcite } \\
\text { (PDB; \%o) }\end{array}$ & $\begin{array}{c}\delta^{18} \mathrm{O} \\
1 \sigma \\
\end{array}$ & $\begin{array}{c}\Delta_{47^{* *}} \\
(\% \circ ; \text { ARF })\end{array}$ & $\begin{array}{c}\Delta_{47}{ }^{*} \\
(\% \circ ; \text { ARF })\end{array}$ & $\begin{array}{l}\Delta_{47} \\
1 \sigma \\
\end{array}$ & $\begin{array}{l}\Delta_{47} \\
\mathrm{SE} \\
\end{array}$ \\
\hline Carmel Chalk & -2.292 & 0.012 & -4.335 & 0.027 & 0.694 & 0.704 & 0.035 & 0.012 \\
\hline Carmel Chalk & -2.216 & 0.006 & -4.289 & 0.014 & 0.702 & 0.712 & 0.018 & 0.006 \\
\hline Carmel Chalk E10 & -2.229 & 0.006 & -4.332 & 0.011 & 0.650 & 0.660 & 0.044 & 0.015 \\
\hline Carmel Chalk E11 & -2.263 & 0.002 & -4.318 & 0.009 & 0.691 & 0.701 & 0.058 & 0.019 \\
\hline Carmel Chalk E12 & -2.274 & 0.003 & -4.278 & 0.016 & 0.649 & 0.659 & 0.041 & 0.014 \\
\hline Carmel Chalk E9 & -2.312 & 0.003 & -4.194 & 0.013 & 0.676 & 0.686 & 0.034 & 0.011 \\
\hline Carmel Chalk G4 & -2.196 & 0.004 & -4.299 & 0.012 & 0.663 & 0.673 & 0.040 & 0.013 \\
\hline Carrara Marble D12 & 2.164 & 0.008 & -2.050 & 0.022 & 0.391 & 0.401 & 0.038 & 0.013 \\
\hline Carrara Marble D8 & 2.131 & 0.005 & -2.073 & 0.015 & 0.397 & 0.407 & 0.059 & 0.020 \\
\hline Carrara Marble G2 & 2.161 & 0.006 & -1.960 & 0.015 & 0.408 & 0.418 & 0.036 & 0.012 \\
\hline Carrara Marble G5 & 2.151 & 0.003 & -1.953 & 0.019 & 0.397 & 0.407 & 0.033 & 0.011 \\
\hline ETH-2 & -10.172 & 0.004 & -18.912 & 0.016 & 0.295 & 0.305 & 0.044 & 0.015 \\
\hline ETH-3 B11 & 1.634 & 0.004 & -2.147 & 0.016 & 0.682 & 0.692 & 0.034 & 0.011 \\
\hline
\end{tabular}

** An acid fractionation correction of $+0.082 \%$ was applied (Defliese et al., 2015).

* An acid fractionation correction of $+0.092 \%$ was applied (Henkes et al., 2013). 
Table 3. Formation temperatures predicted using previously published calibration equations.

\begin{tabular}{|c|c|c|c|c|c|c|c|c|c|c|c|}
\hline \multirow{2}{*}{$\begin{array}{l}\text { Sample } \\
\text { ID }\end{array}$} & \multirow[b]{2}{*}{ Mineral } & \multirow[b]{2}{*}{ Phase } & \multirow[b]{2}{*}{ Formation } & \multicolumn{2}{|c|}{ Sample } & \multirow{2}{*}{$\begin{array}{c}\Delta_{47^{* \star}} \\
(\% \text {; abs })\end{array}$} & \multirow{2}{*}{$\begin{array}{l}\Delta_{47} \\
1 \mathrm{SE}\end{array}$} & \multicolumn{2}{|c|}{ Defliese et al. Kluge et al. } & \multirow{2}{*}{$\begin{array}{c}\text { Schauble et al. (2006) } \\
+0.268 \text { (Guo et al., 2009) } \\
\mathrm{T}\left({ }^{\circ} \mathrm{C}\right)\end{array}$} & \multirow{2}{*}{$\begin{array}{l}\text { Zaarur et al. } \\
\qquad(2013) \\
\mathrm{T}\left({ }^{\circ} \mathrm{C}\right)\end{array}$} \\
\hline & & & & $\mathrm{T}_{h}{ }^{*}\left({ }^{\circ} \mathrm{C}\right)$ & $1 \sigma$ & & & $\begin{array}{l}(2015) \\
\mathrm{T}\left({ }^{\circ} \mathrm{C}\right)\end{array}$ & $\begin{array}{l}(2015) \\
\mathrm{T}\left({ }^{\circ} \mathrm{C}\right)\end{array}$ & & \\
\hline 4-86.5 D3 & D3 & very coarse saddle dolomite & Catoche & 175.9 & 7.3 & 0.445 & 0.012 & 199 & 191 & 150 & 116 \\
\hline P184-D3 & D3 & very coarse saddle dolomite & Boat Harbour & 135.9 & 11.2 & 0.445 & 0.012 & 199 & 191 & 150 & 116 \\
\hline 6-216 D3 & D3 & very coarse saddle dolomite & Boat Harbour & 129.4 & 8.5 & 0.437 & 0.006 & 211 & 202 & 158 & 120 \\
\hline 4-86.5 D2 & D2 & zoned med. coarse dolomite & Catoche & 123.6 & 1.0 & 0.456 & 0.007 & 184 & 178 & 141 & 110 \\
\hline $6-138 \mathrm{D} 2 \mathrm{~B}$ & D2 & zoned med. coarse dolomite & Boat Harbour & 121.3 & 9.4 & 0.509 & 0.003 & 128 & 126 & 102 & 86 \\
\hline 6-138-D2B-F & D2 & zoned med. coarse dolomite & Boat Harbour & 121.3 & 9.4 & 0.490 & 0.004 & 145 & 142 & 115 & 94 \\
\hline 6-184 D2B & D2 & zoned med. coarse dolomite & Boat Harbour & 103.1 & 6.2 & 0.532 & 0.012 & 109 & 108 & 89 & 76 \\
\hline R1-116-D2 & D2 & zoned med. coarse dolomite & Aguathuna & 73.4 & 3.2 & 0.486 & 0.028 & 150 & 146 & 118 & 96 \\
\hline P81-D1 & D1 & dolomicrite & Boat Harbour & - & - & 0.514 & 0.010 & 124 & 122 & 99 & 84 \\
\hline P92-D1 & D1 & dolomicrite & Boat Harbour & - & - & 0.530 & 0.010 & 111 & 110 & 90 & 77 \\
\hline
\end{tabular}

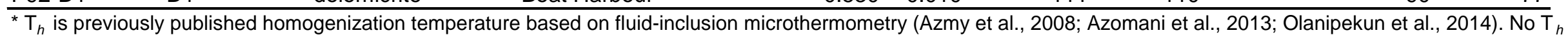

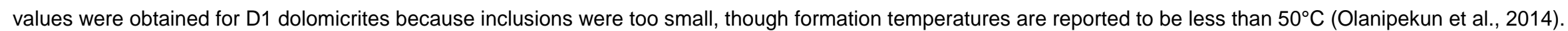

${ }^{* *}$ An acid fractionation correction of $+0.082 \%$ was applied (Defliese et al., 2015).

The temperature estimates of Defliese et al. (2015) and Zaarur et al. (2013) are based on extrapolations of their published equations. 


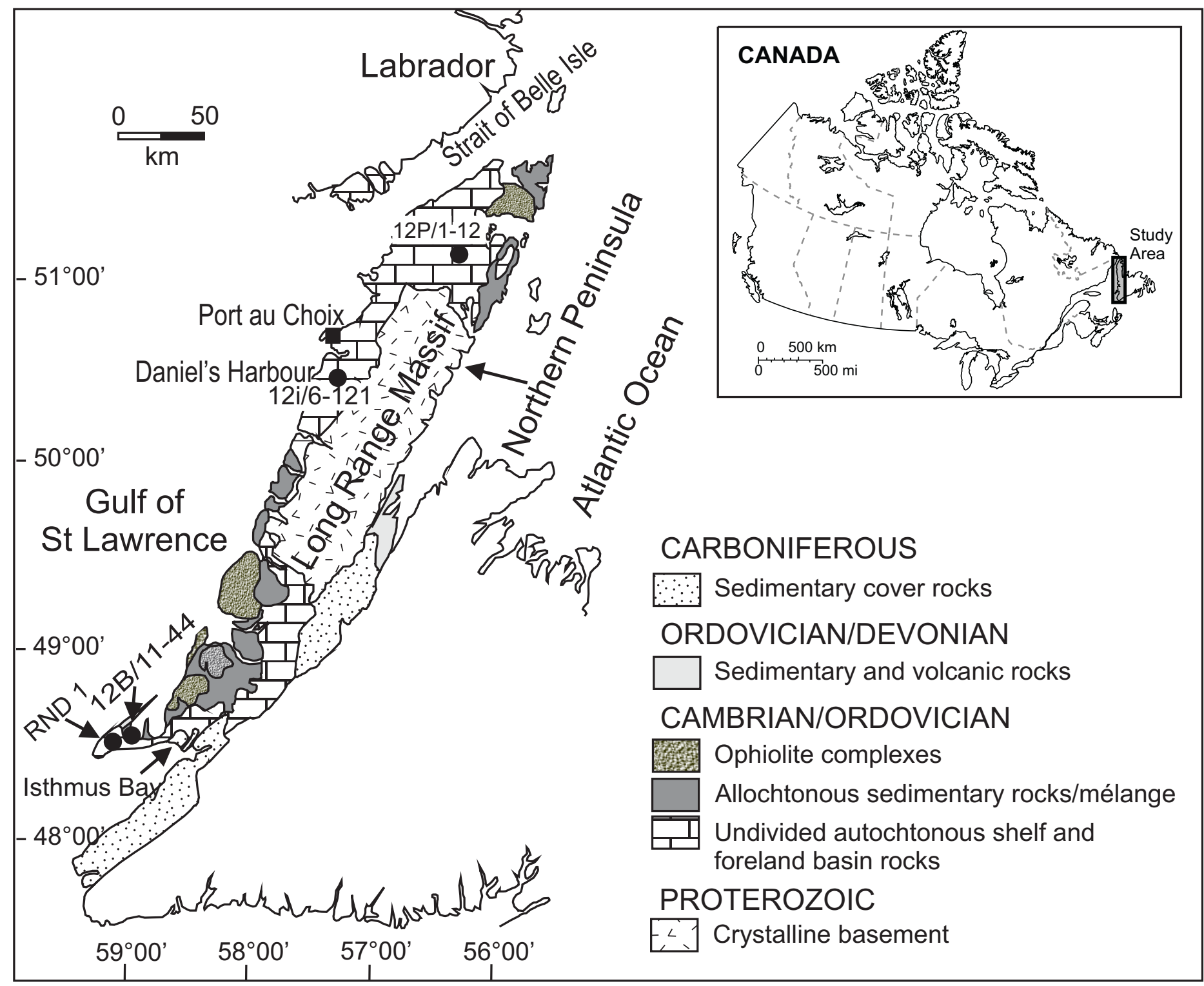



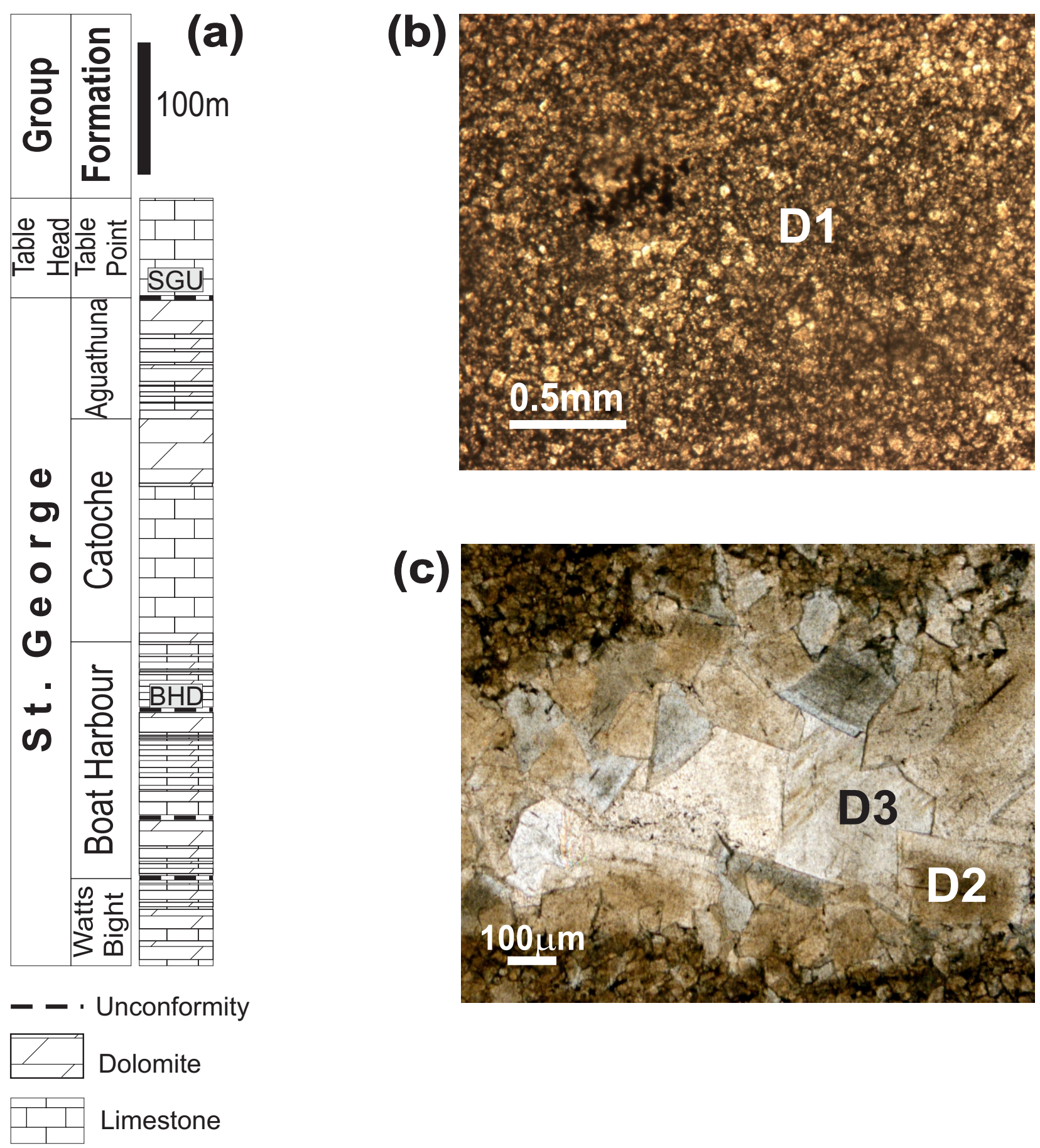

\section{(c)}

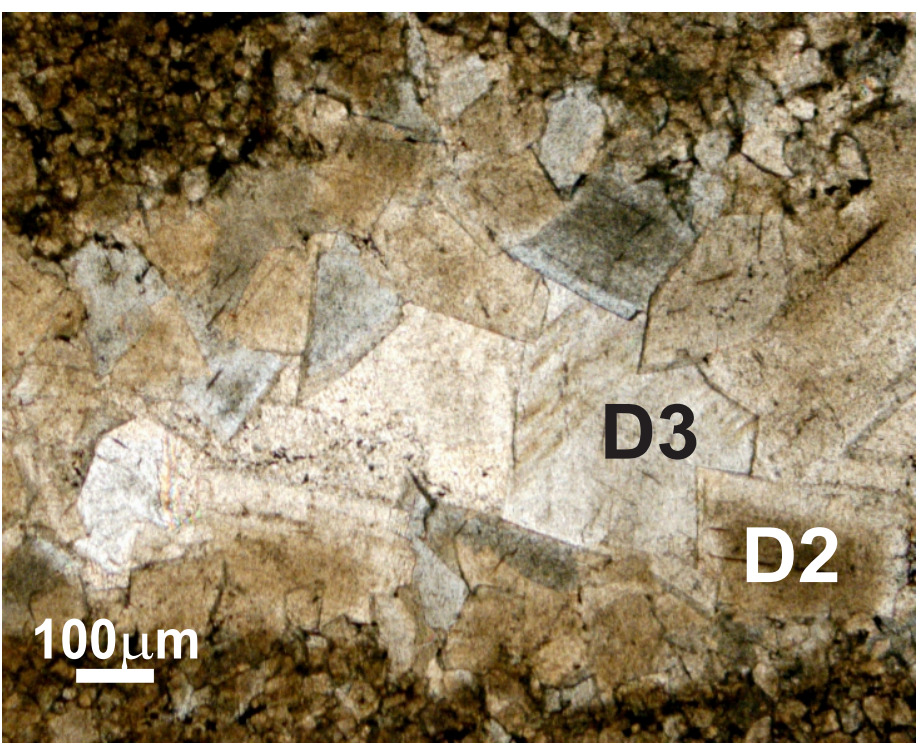

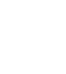




\section{Figure 3}

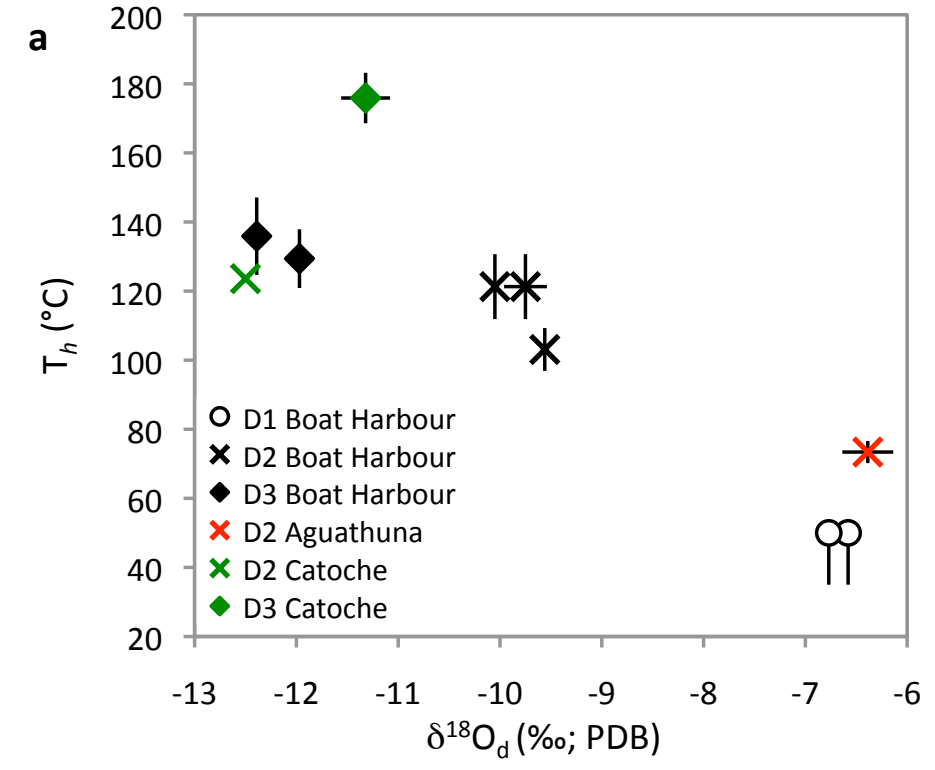

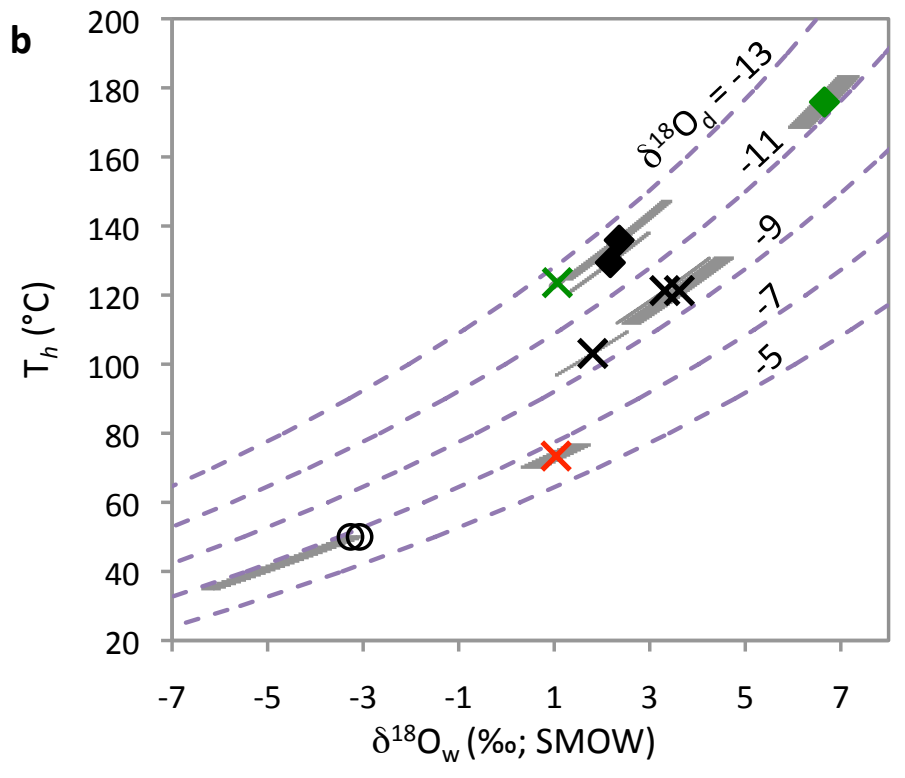


Figure 4

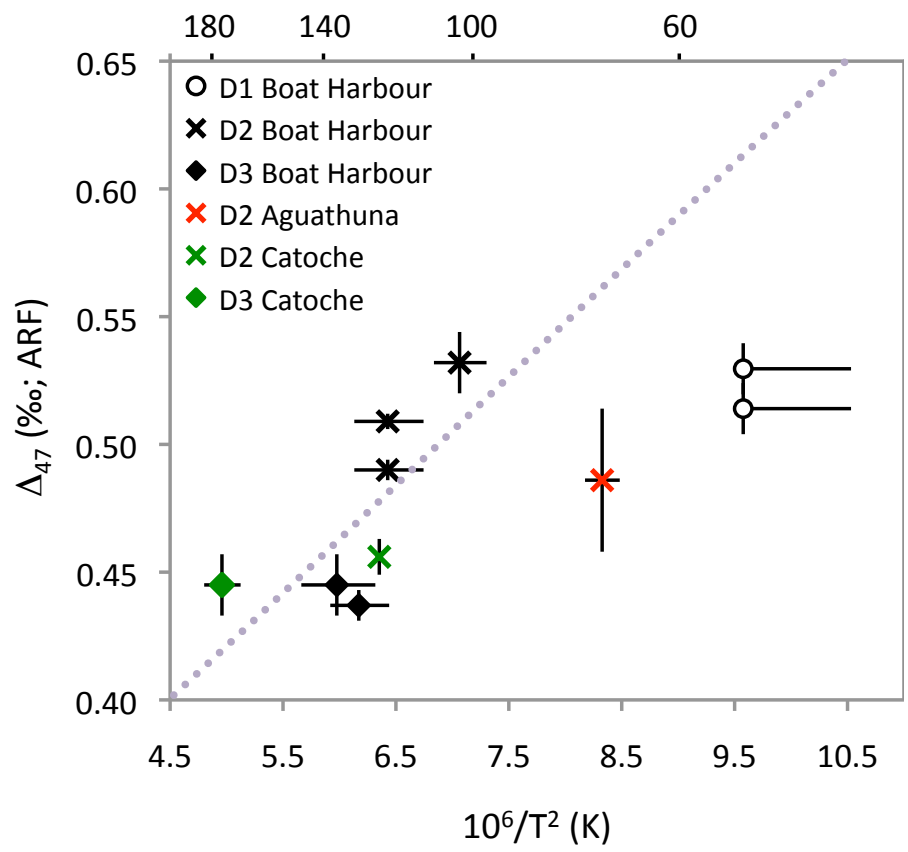


Figure 5

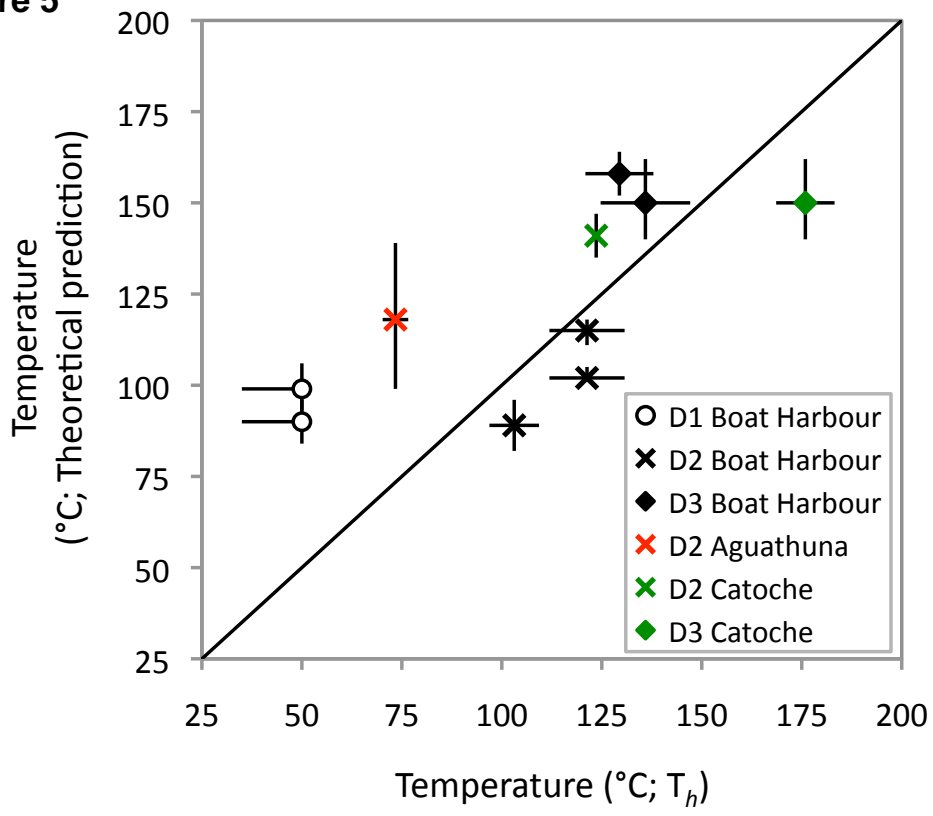


a

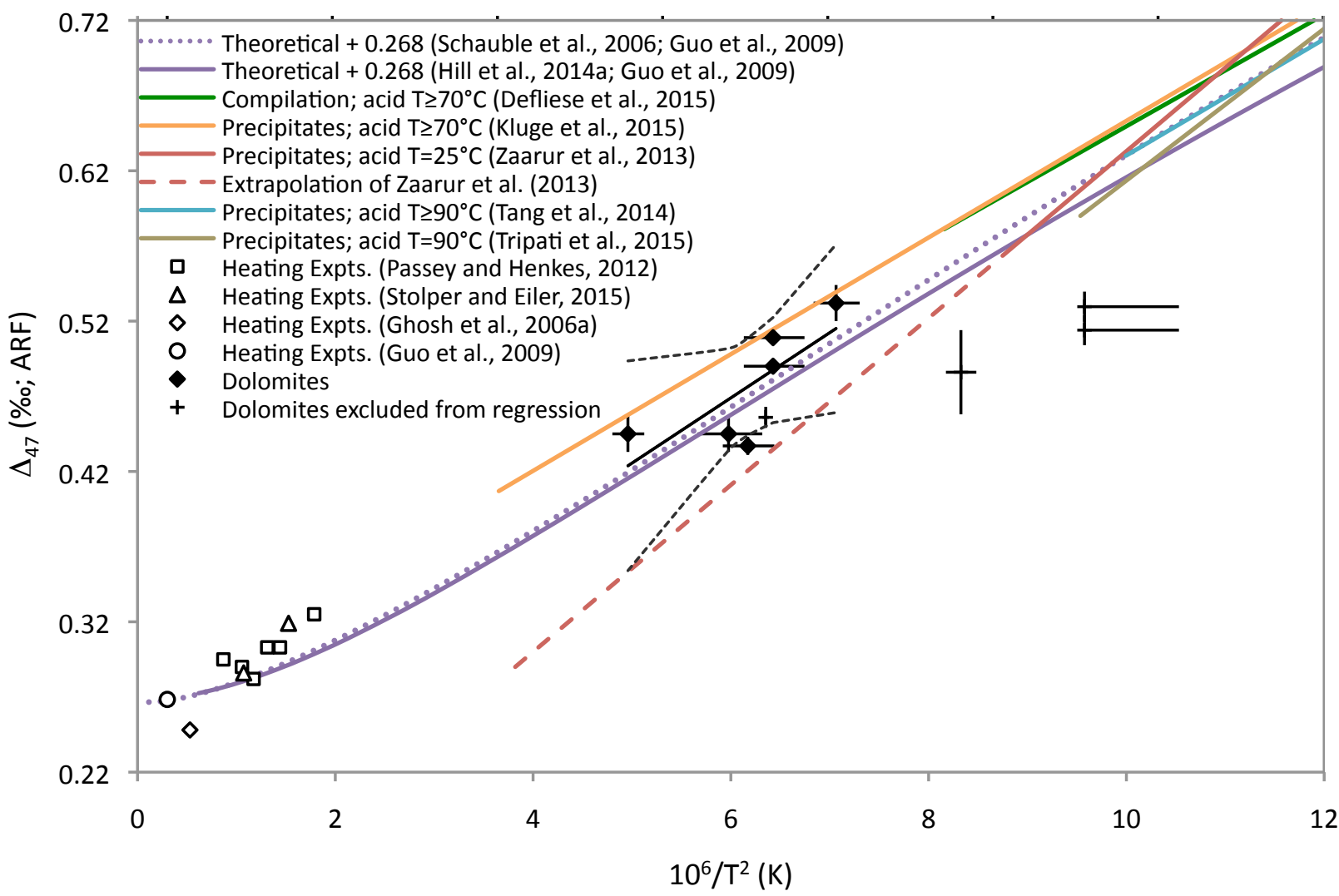

Temperature $\left({ }^{\circ} \mathrm{C}\right)$

b

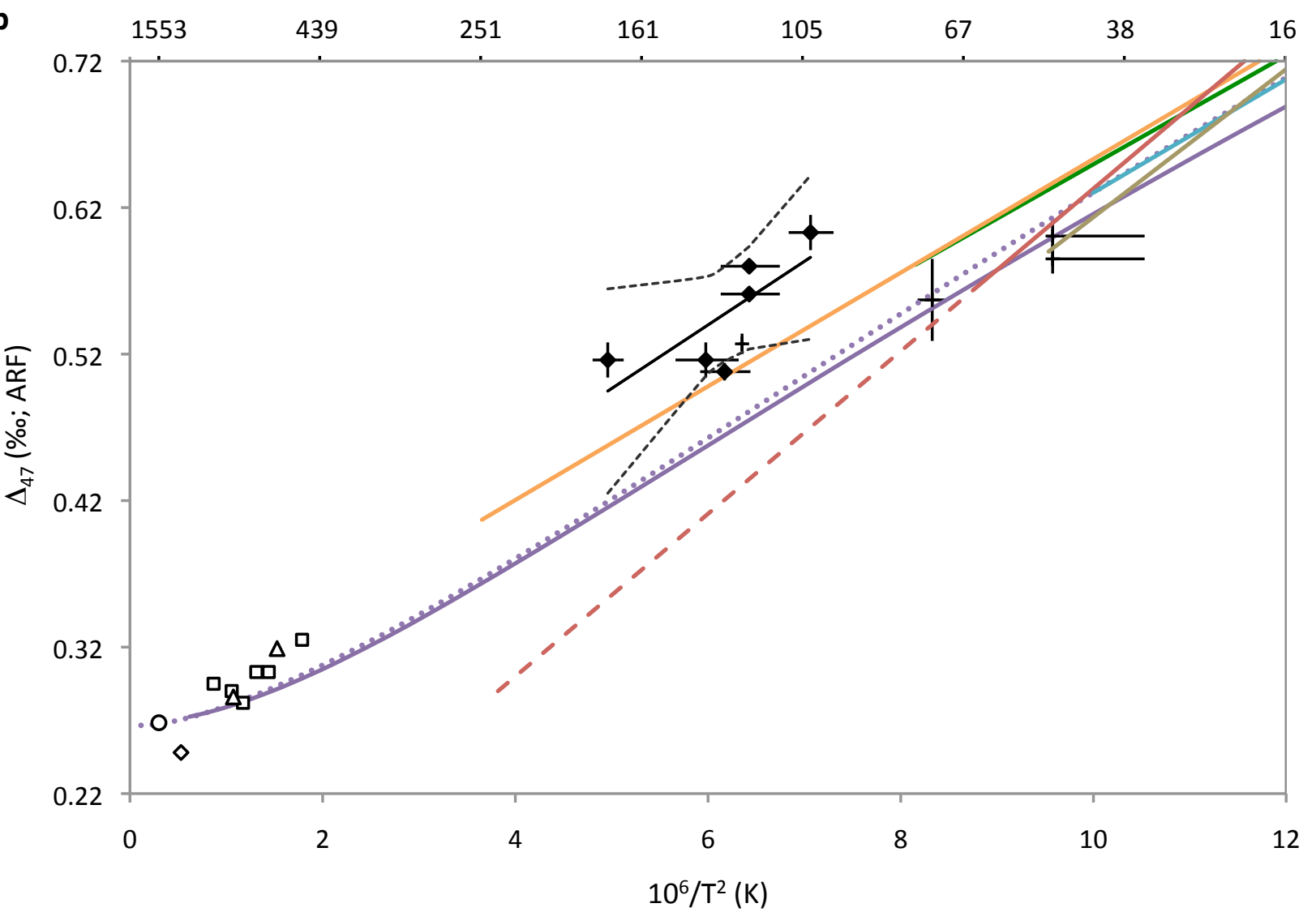

